\title{
K INTERPRETACI ARCHEOLOGICKÉHO VÝZKUMU BAZILIKY SV. PETRA A PAVLA NA VYŠEHRADĚ
}

\author{
BOŘIVOJ NECHVÁTAL
}

\begin{abstract}
Abstrakt: Nový archeologický výzkum Národni kulturni památky Vyšehrad byl zahájen v roce 1966 a provádí jej Archeologický ústav (dřive ČSAV, dnes AV ČR). Výzkum kapitulního kostela sv. Petra a Pavla, druhé hlavni baziliky přemyslovského státu, byl zahájen v roce 1968. V letech 1968-1991 byl odkryt celý půdorys stavby ve složitých terénních podminkách vyšehradského hřbitova. V letech 1981-1985/1986 byl proveden výzkum interiéru stavby. Byly zjištěny dvě románské etapy-první z doby založení kostela (kolem r. 1070) králem Vratislavem II. (1061-1092), druhá z obdobi před rokem 1129, za jeho syna Soběslava I. (1125-1140). Stavba byla zjištěna jako trojlodni bazilika dvouchórová (o rozměrech $53 \times 17 \mathrm{~m}$ ). Dalši dvě stavebni etapy byly gotické. První začala po roce 1249 a trvala do počátku 14. století. Měli na ní podil děkan Držislav a matka Karla IV., poslední přemyslovská královna Eliška Přemyslovna (1292-1330). Počátek druhé, z podnětu Karla IV., spadá do obdobi po roce 1369, byl zde napodoben systém jihofrancouzských bazilik v Toulouse a v Narbonnu. Podle výsledků archeologického výzkumu dosáhl kapitulní komplex koncem 14. a počátkem 15. století délky $110 \mathrm{~m}$. Základni přehled o stavbě umožňuje upozornit na některé interpretačni možnosti a také na některé otevřené problémy, nap̌r. otázku druhé románské etapy před rokem 1129, oltářní desky z baziliky sv. Petra v Pise a jejího vztahu k Vyšehradu či reliéfního medailonu s motivem orla (?) nebo kruhové stavby baptisteria před západním průčelím raně románské baziliky.
\end{abstract}

Klíčová slova: bazilika - druhá románská etapa - oltárnni deska - reliéfni medailon - kruhová stavba-baptisterium.

\section{The Interpretation of Archaeological Research into the Basilica of Sts. Peter and Paul at Vyšehrad}

Abstract: The most recent archaeological research into the Vyšehrad national cultural monument was launched in 1966 and has been conducted by the Archaeological Institute (formerly of ČSAV, now the Science Academy of the CR). Research into the chapter Church of Sts. Peter and Paul, the second most important basilica of the Premyslid state, started in 1968. In 1968-1991 the whole ground plan of the construction was uncovered, in complicated terrain conditions of the Vyšehrad cemetery. In 1981-1985/1986 the interior of the building was investigated and two Romanesque phases were disclosed: the first one from the period when the church was founded (around 1070) by King Vratislav II (1061-1092), the second from the period before the year 1129, under Vratislav's son Soběslav I (1125-1140). The construction was designed as a triple-nave, double-gallery basilica (with dimensions of $53 \times 17 \mathrm{~m}$ ). The next two building phases were Gothic. The first started after 1249 and lasted until the early 14th century. The second phase, initiated by King Charles IV, began after 1369 and imitated the style of the basilicas in Toulouse and Narbonne in southern France. According to the results of archaeological research, the chapter complex was $110 \mathrm{~m}$ long in the late 14 th century and the early 15th century. The basic overview of its building history enables to point out some interpretation possibilities and unresolved issues such as the issue of the second Romanesque phase before 1129, the altar panel from the Basilica of St. Peter in Pisa and its relation to Vyšehrad, a relief medallion with the motif of an eagle (?) and the circular baptistery construction in front of the west frontage of the early Romanesque basilica.

Key words: basilica - second Romanesque phase - altar panel - relief medallion - circular construction - baptistery.

Nový archeologický výzkum Národní kulturní památky Vyšehrad byl zahájen v roce 1966. Na žádost primátora hlavního města Prahy Ludvíka Černého jej začal provádět Archeologický ústav ČSAV (dnes Akademie věd České republiky; dále jen ARÚ AV ČR). Přinesl množství zásadních poznatků, které jsou důležitým př́spěvkem k poznání raně středověkého hradiště, jež je spojováno s nejstaršími českými dějinami. Výzkum kapitulního kostela sv. Petra a Pavla, druhé hlavní baziliky přemyslovského státu, vede rovněž ARÚ AV ČR. Po prrípravných pracích a shromáždění dokumentace začala v roce 1968 první výzkumná sezóna.

Při revizi nálezové situace a ověřování zprávy od obětavého vlastivědného pracovníka Stanislava Křížka (1921-1985) byla učiněna zmínka o nálezech kvádrového a lomového opuko- 


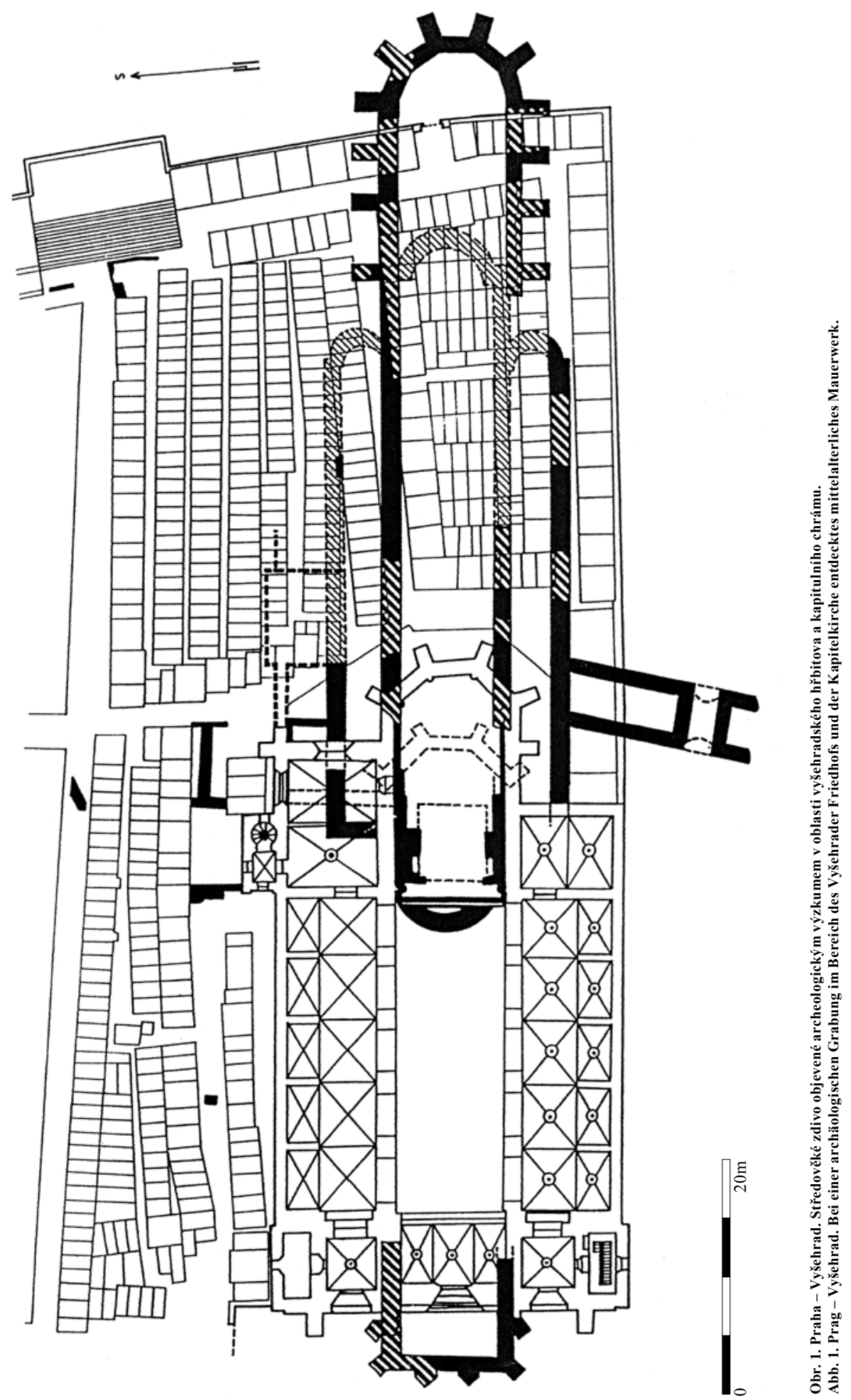




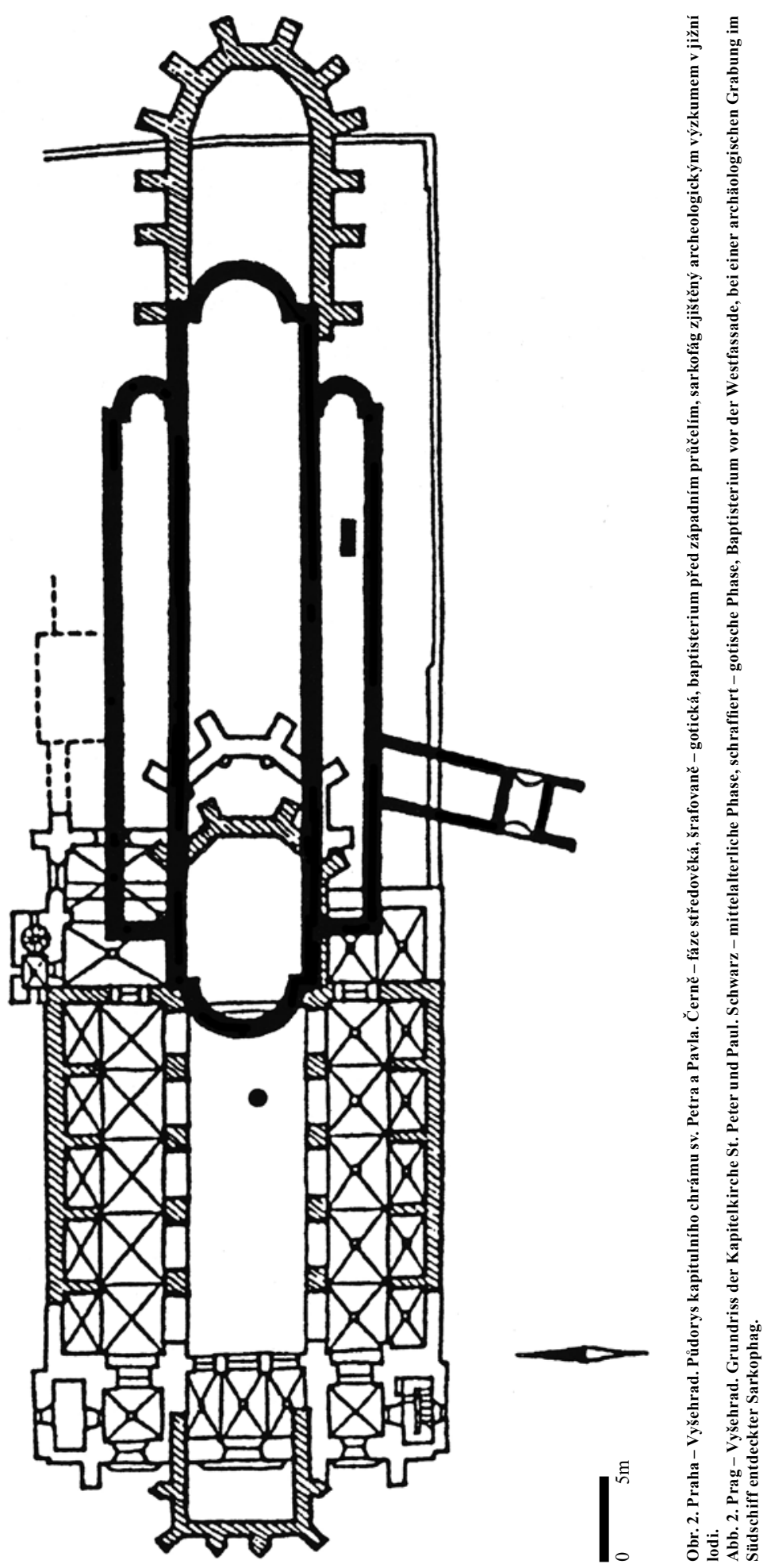


vého zdiva. Při stavebních úpravách rodinné hrobky Rirenschaftů, v roce 1964 nebo 1965, bylo zjištěno na sever od hrobu B. Němcové, ve východní části vyšehradského hřbitova u východní vstupní branky. Významná je také zpráva sochaře a sběratele Karla Vlačihy (1850-1932) o nálezu románského zdiva při stavbě Slavína. Již v první výzkumné sezóně v roce 1968 bylo nalezeno v třetí a čtvrté mechanické vrstvě $(70-90 \mathrm{~cm})$ značné množství opukových zlomků a stavební suti (v sondách S-122, S-123 a S-124) za východní brankou vyšehradského hřbitova. Kryly korunu zdiva, které bylo při předběžné interpretaci označeno za část interiéru stavby sakrálního charakteru, části apsidálního závěru. Po zjištění úhlu, který mezi sebou svíraly dvě objevené zdi, byl vypočítán pravděpodobný rozsah stavby. Poté, co byl proveden výkop, byla nalezena stavba, jejíž objevená část měla kruhový půdorys. Na vnější straně byl členěn systémem krátkých robustních opěrných pilírů. Na vnitřní straně v ose pilířu a předzákladu byla vždy trojdílná hruškovitá paprsčitě členěná přípora s tupým nosem. Na jižní, ale především na severní straně byla dobře v celistvosti zachována. Z hlediska interpretace funkce stavby se nabízela úvaha, zda nejde o samostatnou centrální stavbu, oktogon nebo desetiúhelník, nebo o část kaple některé ze středověkých kanovnických rezidencí. Tehdy, tedy v době výzkumu se jevila třetí možnost - že jde o kněžiště s částí hlavní lodi - jako nejméně pravděpodobná. Ovšem na půdorysu stavebního objektu bylo nápadné, že osa stavby byla značně blízká s osou dnešního kapitulního kostela sv. Petra a Pavla.

Po provedení prvních sond u východní branky hřbitova (S-114 a především S-122, S-123 a také S-124) a Slavína a sond ve východní části hřbitova (na jižní straně S-155, S-146, S-147) a na střední hlavní cestě (S-141, S-144) bylo zjištěno, že jde o neznámý velký sakrální komplex. Teprve při pokračujícím výzkumu v oblasti hřbitova směrem západním mohl být jednoznačně interpretován jako bazilika sv. Petra a Pavla. V letech 1968-1991 se ve složitých terénních podmínkách Vyšehradského hřbitova podařilo postupně odkrýt celý půdorys stavby. Výzkum zde mohl být proveden jen díky pochopení vedení Pohřební služby hl. m. Prahy a především vedoucího právního oddělení JUDr. Antonína Funka (1909-1980).

Po přípravných pracích a studiu písemných pramenů a ikonografického materiálu byl v letech 1981-1985/1986 se souhlasem státních a památkových orgánů a především vlastníka Královské kolegiátní kapituly sv. Petra a Pavla proveden výzkum interiéru stavby. Po dobu archeologického výzkumu nebyl nikdy přerušen liturgický provoz kapitulního kostela.

Při průzkumu byly zjištěny dvě románské etapy. První je z doby založení kostela (kolem r. 1070) knížetem a prvním českým králem Vratislavem II. (1061-1092). Druhá etapa pokračovala podle písemných pramenů za jeho syna Soběslava I. (1125-1140) v období před rokem 1129. Podle archeologického výzkumu byla nejdříve postavena románská trojlodní bazilika dvouchórová (o rozměrech $53 \times 17 \mathrm{~m}$ ). Na východě byla ukončena třemi půlkruhovými apsidami, na západní straně hlavní lod' přecházela do půlkruhové apsidy. Půdorysná koncepce byla podobná jako u baziliky Spytihněvovy na Pražském hradě. Je to druhý podobný př́klad na našem území. Baptisterium objevené během výzkumu před západním průčelím svědčí o staré liturgické praxi křtu, s jakou se setkáváme na Velké Moravě. V jižní lodi byl nalezen raně středověký sarkofág v původní terénní situaci. Kostel také obsahoval panovnickou kryptu, která byla podle interpretace výsledků výzkumu před hlavním oltářem na východní straně mezi dvěma věžemi, zvonicemi. Jsou zmiňovány v písemných pramenech k roku 1349 - „inter campanilia“. Poloha krypty nebyla $\mathrm{v}$ době výzkumu, ani později přístupná. $\mathrm{V}$ kryptě byl pohřben zakladatel kapitulního kostela, první český král Vratislav II. († 14. ledna 1092), a všichni jeho nástupci, kteří vládli z tohoto druhého centra českého přemyslovského státu až do poloviny 12 . století.

Další dvě stavební etapy byly gotické. První začala po roce 1249 , kdy kostel v bojích mezi králem Václavem a jeho synem Přemyslem vyhořel. Začíná postupná oprava a přestavba, která trvala až do počátku 14. století. Měl na ní podíl děkan Držislav, patrně i probošt Jan III. Volek, který byl nemanželským synem krále Václava II. (1271-1305), a především jeho nevlastní sestra Eliška Přemyslovna (1292-1330). Zemřela na Vyšehradě 28. 9. 1330, na den sv. Václava, v domě zmíněného probošta Jana III. Volka. Podle výsledků archeologického výzkumu byla raně gotická přestavba datována do 30. let 14. století. Její zahájení bylo současně jak na východní straně, 
tak i na straně západní před románským trojlodím. Rozsah v západní části přesně neznáme, i když prohloubený analytický výzkum přináší další důležitá zjištění (Nechvátal 2004, 73n).

Druhá gotická etapa začala za Karla IV. v období po roce 1369. Je vrcholně gotického charakteru a poslední ze sedmi stavebních etap kapitulního kostela, kterou mohl ještě výzkum sledovat. Byla zahájena z podnětu Karla IV., který touto novou fundací navázal na původní stavební záměr své matky. Výstavba nového chrámového trojlodí arrasovského schématu byla provedena se sledem bočních kaplí, které byly umístěny na boku jednotlivých lodí. Jde o druhou stavbu tohoto typu na našem území po svatovítské katedrále. Podle rekonstrukce V. Mencla, která dosud nejvíce vyhovuje našemu dosavadnímu poznání, byl na Vyšehradě napodoben systém jihofrancouzských bazilik v Toulouse a Narbonnu. Podle výsledků výzkumu dosáhl kapitulní komplex koncem 14. a počátkem 15. století délky $110 \mathrm{~m}$ a byl jednou $\mathrm{z}$ nejdelších staveb svého druhu v předhusitské Praze.

Základní přehled o vývoji stavební podoby kapitulního kostela sv. Petra a Pavla na Vyšehradě současně umožňuje také upozornit na interpretační možnosti a některá dosud neuspokojivá řešení stále otevřených otázek, které chceme blíže poznat a podrobněji se jim věnovat. Jsou to tyto: druhá románská etapa před rokem 1129, oltářní deska z baziliky sv. Petra v Pise a Vyšehrad, reliéfní medailon s motivem orla a kruhová stavba baptisteria před západním průčelím raně románské baziliky.

\section{Druhá románská etapa před rokem 1129}

Vyšehradský kapitulní chrám sv. Petra a Pavla záhy po svém dokončení (před r. 1080) podstoupil za knížete Soběslava I. (1125-1140), před rokem 1129, další stavební úpravu - ta je i detailněji zmíněna v písemných pramenech (FRB II, 206; CDB I, 112 č. 111). Na její interpretaci není jednotný názor, i když zachovaný text o opravě je na svou dobu poměrně obsáhlý. Kromě vybavení interiéru, jehož kvalitě je rovněž věnována delší pozornost, je nutno si všimnout textu v kronice Kanovníka Vyšehradského, který blíže charakterizuje vlastní opravu stavby (FRB II, 206-207).

V českém překladu K. Hrdiny čteme: „Téhož roku obnovil kniže Soběslav kostel vyšehradský, jejž jeho otec, král Vratislav blahoslavené paměti, vystavěl pro spásu duše své i své choti a svého potomstva se svolením a z moci nejslavnějšího papeže Alexandra a sedmdesáti dvou otců; řečený biskup svaté církve řimské poslal k potvrzení důstojnosti tohoto posvátného zrrizení služebniküm tohoto kostela: knězi, jáhnovi a podjáhenovi a též proboštovi prostřednictvím Jana, biskupa tuskulského, a Petra, probošta u sv. Jiří, mučedníka, sandály a mitry a povolil jim, aby jich na znameni apoštolské moci navždy uživali. Když se o těchto věcech stalo rozhodnutí a opatřní, podřídil řečený král tento kostel svaté církvi v Řimě. Založil jej tím, že přinesl na vlastních ramenou dvanáct plných nůši kameni ke cti Spasitele tak, jak to učinil císař Konstantin při založeni kostela řmského. Učinil jej tedy svobodným a Soběslav, jak jsme pověděli, jej obnovil a obnovený skvěleji zvelebil: dal malovati stěny, zavěsil v něm zlatý kruhový svícen, jenž váži dvanáct hřiven zlata, osmdesát hřiven stříbra, médi a železa nepočitaje, podlahu dal okrášliti hlazenými kameny, přidal bočni lodi, kolem běžicí, přistavěl na dvou stranách krovy, opatřil cihlovým krytem celý vršek kostela i střechy, dal pokrýt klášter a všechna hospodářská staveni; kromě toho rozmnožil počet kanovnikủ toho kostela a obdařil je dalšimi platy, dvory a jinými statky“ (První pokračovatelé Kosmovi, 20-21).

Při interpretaci textu je možno zprávu o zř́izení stropů spojit s bočními loděmi. Nejkomplikovanější je situace termínu ,porticus in circuitu“. Překlad volného charakteru by mohl znamenat, že byl Soběslavem zřízen portikus „kolem dokola“, jak na to již upozornil J. Čarek při svém výkladu textu (1947, 182-183). Kdyby byla zprávou míněna mezilodní arkáda, bylo by to vyjádření nepřesné. Arkádu bylo by si možno představit jen po stranách, a nikoli dokola. Kostel byl stavěn se záměrem vytvořit protiváhu kostela a kapituly svatovítské. Nelze si ho představit jako jednolodní, již od počátku byl trojlodní bazilikou, jak doložil archeologický výzkum. Nutnost hledat stavební útvar, který by této skutečnosti vyhovoval, cítil již ve své práci o nejstarších 
bazilikách V. Birnbaum. Přijatelné vysvětlení - které sám navrhoval -, jak interpretovat uvedené místo zprávy, nakonec označil jako útvar, který na naších památkách zatím neznáme (Birnbaum 1919, 8-10). Byl to předpoklad existence arkádového předdvoří, nebo přímo nádvoří před chrámovým průčelím. Rozhodnutí mohl přinést pouze archeologický výzkum, který tuto možnost naznačuje na severní straně v místě sakristie a v místě styku severní lodě s kapitulním domem. Situace je o to zajímavější, že starší gotická stavba měla malé atrium na západní straně - jeho podobu zachytil J. Mocker před zbouráním roku 1888. Datuje se od druhé poloviny 13. století až do druhé poloviny 14. století (Benešovská 1991; 2001).

Nově je podle V1. Denksteina interpretována zpráva o zlatém kruhovém lustru, který byl zavěšen při opravě v roce 1129. Autor uvádí, že šlo o kolový korunní lustr podobného typu, jako byl lustr zavěšený v kostele v Hildesheimu v 11. století, zpodobující apokalyptické Boží město Nebeský Jeruzalém. Předpokládá, že tento jediný lustr byl vzorem a př́ikladem lustru vyšehradského (Denkstein 1992, 83-91).

V oblasti vyšehradského hřbitova zjistil archeologický výzkum (ca 35 m východně od závěru jižní lodi dnešního kostela) část zahloubené apsidy a úseky základového zdiva jižní lodi, která se na apsidu zjevně vázala a která pokračuje až pod dnešní stavbu (Nechvátal 2004, 247, tab. XVII.). Dále byly zjištěny další zbytky základového zdiva za sakristií na severní straně u dnešního kněžiště. Tato skutečnost umožnila společně se zdivem odkrytým dalšími archeologickými výzkumy v oblasti interiéru dnešní kapitulní stavby rekonstruovat půdorysnou podobu raně středověké trojlodní baziliky, která byla součástí Vratislavova založení. Bazilika měla přibližně 7,5 m širokou hlavní lod' a ca 3,6 m široké boční lodě. Její délka byla ca $53 \mathrm{~m}$ a šířka $17 \mathrm{~m}$. Dále se díky průzkumu ukázalo, že situace románského mostu odpovídá př́mé spojnici mezi královskou akropolí a interiérem kapitulního kostela. Ani přes intenzivní výzkum v oblasti vyšehradského hřbitova neznáme situaci dvou zřejmě symetricky situovaných věží, mezi nimiž byla knížecí a královská krypta. V této souvislosti byla také ověřena hypotéza o starším původu barokní zvonice, která byla v závěru neogotické přestavby (v letech 1885-1903) zbořena. Když byla její poloha vynesena do plánu archeologického výzkumu v oblasti vyšehradského hřbitova, bylo zjištěno, že její jižní zed' byla př́imo na severní obvodové zdi románské baziliky, plně ji respektovala, a je zřejmé, že podle výsledků archeologického výzkumu byla do ní provázána (Nechvátal 2004, 247, tab. XVII.). Znamená to, že po určitý blíže neurčený čas byla současná s funkcí baziliky.

Při řešení problematiky druhé románské etapy baziliky je třeba upozornit na interpretaci termínu porticus, se kterým se setkáváme při zprávě o stavební situaci před rokem 1129 . Termínu se také věnoval J. Cibulka v souvislosti s výkladem některých zpráv písemných pramenů k svatováclavské rotundě (1934, 395-398). Podle jeho výkladu, v němž termín obsáhle rozebírá, má slovo porticus nejméně čtyři významy: za prvé může znamenat boční lod', chodbu nebo ochoz u rotundy, za druhé apsidu, za třetí atrium, nebo za čtvrté předsíň nebo bránu. Nakonec se rozhodl pro nejprriměřenější interpretaci slova porticus, a to jako předsíň nebo vstupní síň (Cibulka 1934, 398).

\section{Oltářní deska z baziliky sv. Petra v Pise a Vyšehrad}

Polovinu oltářní desky z baziliky sv. Petra v Pise obdržel Karel IV. v době své římské korunovační cesty v roce 1355. O jeho návštěvě v Pise se zachovala řada písemných zpráv, na které upozornila v poslední době ve své studii o pisánském oltáři apoštola Petra v chrámu sv. Petra a Pavla na Vyšehradě H. Soukupová (2012, 166-177). Práci doprovází petrografický rozbor úlomku oltářní desky z kostela San Pietro a Grado v Pise, který provedl J. Zavřel (2012, 180183). Osud původní desky neznáme, mohla být ztracena v době husitské revoluce, nebo druhotně použita do některého $z$ barokních oltářù. $V$ době regotizace již není o oltáři žádných zpráv.

Z písemných zpráv je možno pobyt Karla IV. v Pise a všechny hlavní události s tím související rekonstruovat. Do Pisy dojel Karel IV. osmnáctého ledna a zdržel se dva měsíce. Jedna z prvních cest $v$ Pise vedla pravděpodobně do dómu, kde v náhrobku od Tina di Camaino byly 
ostatky jeho dědečka, císaře Jindřicha VII. († 1313). Podle zmíněných zpráv měl dvakrát navštívit zdejší poutní chrám sv. Petra, který stojí poblíž moře (,ad gradus mare“). Kostel stojí podle tradice v místě, kde snad roku 44 po Kr. na cestě z Antiochie do Říma přistál apoštol Petr. Bouře ho přinesla na pobřeží v dnešní Pise u ústí řeky Arna. Zde měl strávit šest měsíců. Na tomto místě postavil vlastníma rukama kamenný oltář a sloužil první mši v Itálii. Později tu vznikl kostel ke cti apoštola Petra. Karel IV. se při své cestě nechal seznámit s místní tradicí a také viděl oltár̆, do kterého sv. Petr zasadil kamennou desku, o jejíž část požádal pisánského arcibiskupa.

Celou událost podrobně popisuje H. Soukupová podle tř́ listin zachovaných v Archivu vyšehradské kapituly, které jsou dnes uloženy v Národním archivu v Praze (Soukupová 2012, 169-171). Oltáŕní deska je v současnosti uložena v Muzeu dómu v Pise. Karel IV. část desky, kterou na svou žádost získal, zaslal prostřednictvím svého kaplana a vyšehradského kustoda Siffrida do Avignonu papeži Inocenci VI. (1352-1362), aby ji posvětil a uložil do ní relikvie sv. Petra s ostatky dalších svatých. V zachovaném listu papeži Karel IV. uvádí, že ji chce věnovat vyšehradskému kostelu, který byl založen ke cti sv. Petra, a požaduje, „aby byla slavnostně umistněna na jednom oltáŕi toho vyšehradského kostela“. Papež jeho žádosti vyhověl a 8 . května 1355 ve svém listě z Avignonu sděluje, že kámen posvětil a uložil do něj relikvie a „toužice, aby ten námi vysvěcený kámen a oltár̆, na němž bude v rečeném kostele umistěn, byl navštěvován s náležitou úctou [...]“. Papež současně udělil vyšehradskému kapitulnímu kostelu ve výročí posvěcení kamene odpustky tří let a třikrát čtyřiceti dní a těm, kteří se u oltáře účastní slavnostní mše, odpustky jednoho roku a čtyřiceti dní. Na žádost Karla IV. papež stanovil, že u oltáře, kde bude deska uložena, má sloužit mši pouze prelát nebo biskup, který nosí pallium nebo má pravomoc pallium užívat.

H. Soukupová také upozornila na velikost odpustků, které je možno srovnat pouze s odpustky u největších římských bazilik (S. Maria Maggiore a sv. Petra a Pavla). Bazilika S. Pietro a Grado mare v Pise, která stojí v místě, kde původně býval starý přístav, je dnes vzdálena od moře několik kilometrů kvůli naplaveninám řeky Arna. Dnešní kostel ukončují na východě tři půlkruhové apsidy a na západě velká apsida. Ve východní části baziliky se koná běžná liturgie, v západní je svaté místo - oltár̆ sv. Petra. Jeho polohu uprostřed hlavní lodi osvětlil archeologický výzkum v letech 1919-1925 a v letech 1955-1960 (Sodi 2000, 13-20). Bylo zjištěno, že oltář je umístěn $v$ apsidě starší svatyně, která byla vystavěna $v$ místech římského př́istavu. V průběhu 4. století zde vznikl upomínkový kostel, který byl rozšířen v 7. století a zanikl v 10. století při stavbě dnešní baziliky. Vlastní oltář tvoří podle H. Soukupové, která ho zná z autopsie, granitový sloup, na němž leží část mramorové desky o rozměrech ca $60 \times 60 \mathrm{~cm}$ donedávna skrytá v barokním oltáři. Nad oltářem je gotický baldachýn, který je nesen čtyřmi sloupy a zaklenut je jedním polem kř́ižové klenby. Baldachýn je datován do konce 13. století. Události v Pise v souvislosti s deskou z oltáře sv. Petra velmi podrobně popisuje kronikář Karla IV. Jan Marignola, který se italské výpravy účastnil. Zpráva je umístěna na konci textu jeho kroniky jako jakési vyvrcholení (Marignola 1987, 516).

Na závěr své statě si H. Soukupová klade otázku, kde byl oltář sv. Petra na Vyšehradě, kam byla umístěna deska z oltáře z Pisy. Archeologický výzkum kapitulního kostela sv. Petra a Pavla byl prováděn v letech 1981-1986 v celém rozsahu interiéru dnešní stavby. V hlavní lodi v západní části (sonda S-189) byl objeven poměrně zvláštní útvar, který byl původně interpretován jako součást vstupního prostoru Karlovy baziliky, př́ípadně empory. Nalezený objekt sestává ze tří stran, respektive ze čtyř stran, pokud uvažujeme i západní stranu, kamenného základového pláště o velikosti ca $350 \times 400 \mathrm{~cm}$. V jeho jižní části jsou z druhotného použití zazděny románské a raně gotické stavební články. V severní části je v původním uložení profilované gotické ostění mimo obvodové zdivo. Na severní straně, která je zčásti poškozena, je uložen hrob č. 59 dospělého jedince (viz řez č. 265). Vnější plášt' zdiva na východní straně ohraničuje celý prostor a je plně provázán se zdivem na jižní straně. Stavební nálezová situace umožňuje klást jak zdivo, tak také hrob do předhusitského období. Podle H. Soukupové dovoluje tvar zdiva předpokládat, že jde o oltář chráněný vnější zdí. „Neobvyklá poloha v západni části středni lodi nápadně připomíná polohu pisánského oltářre" (Soukupová 2012, 175). Tato její interpretace může být pravděpo- 


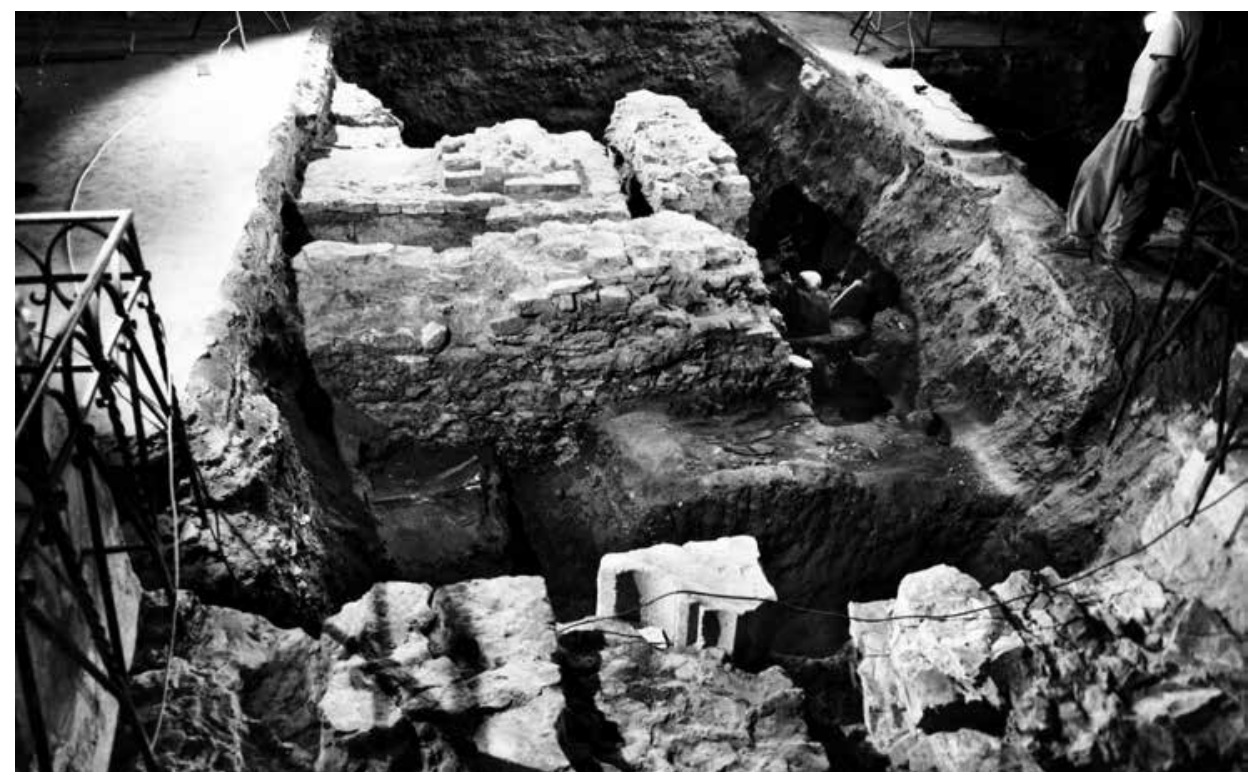

Obr. 3. Praha - Vyšehrad. Sonda S-189, pohled od jihu na soubor středověkých základů. Foto B. Nechvátal.

Abb. 3. Prag - Vyšehrad. Sondierschnitt S-189, Blick von Süden auf einen mittelalterlichen Fundamentkomplex. Foto B. Nechvátal.

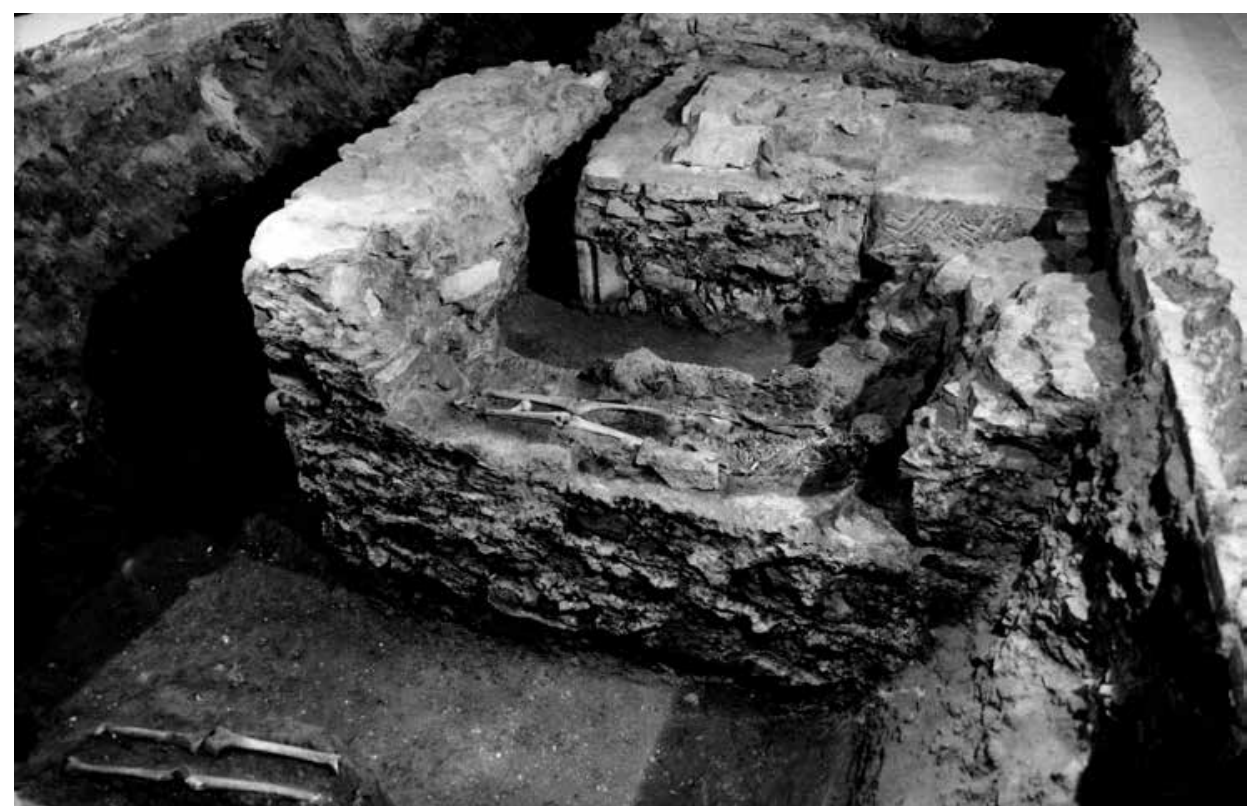

Obr. 4. Praha - Vyšehrad. Sonda S-189, pohled od severu na soubor středověkých základů. Foto B. Nechvátal.

Abb. 4. Prag - Vyšehrad. Sondierschnitt S-189, Blick von Norden auf einen mittelalterlichen Fundamentkomplex. Foto B. Nechvátal.

dobná jako základna oltáře. Ovšem na druhé straně předpokládáme, že hlavní oltář v bazilice Karla IV. byl na východní straně, jak bylo v této době zvykem. Dále známe z doby předhusitské (podle V. V. Tomka) zprávy o kapli sv. Petra z let 1380 a 1396, které ji lokalizují. Snad stála u kapitulní školy, někde v místech na jih od baziliky sv. Vavřince. Je tedy nepravděpodobné, že by byl na Vyšehradě ještě třetí oltář sv. Petra. 


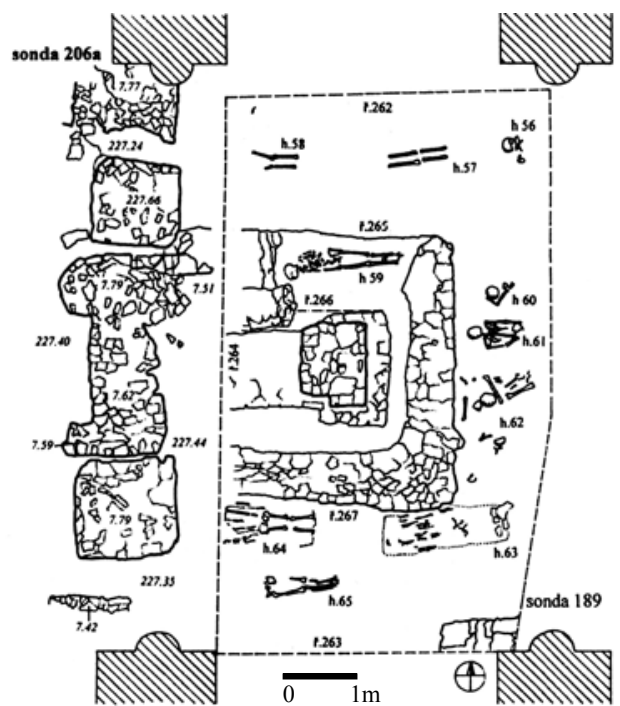

Obr. 5. Praha - Vyšehrad. Sonda S-189, půdorys souboru stř̌edověkých základů.

Abb. 5. Prag - Vyšehrad. Sondierschnitt S-189, Grundriss eines mittelalterlichen Fundamentkomplexes.

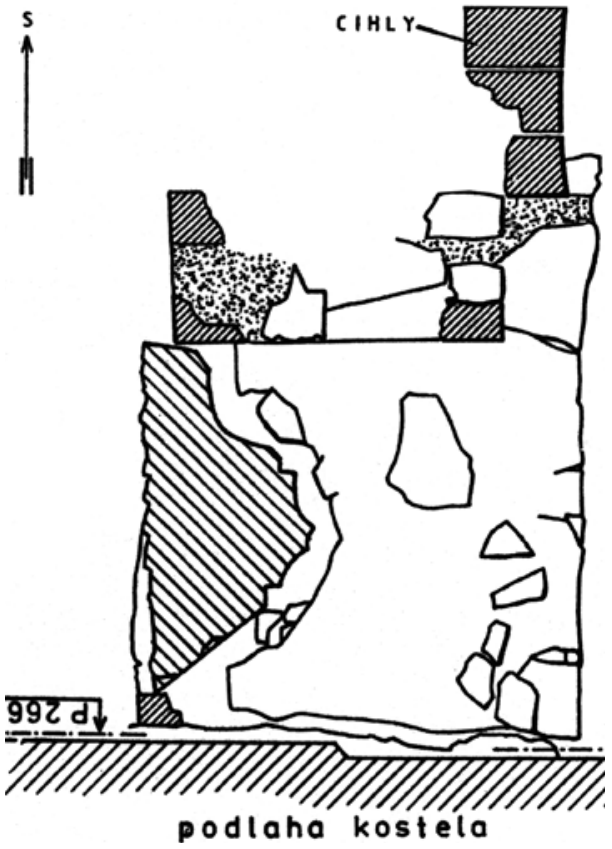

0

Obr. 6. Praha - Vyšehrad. Sonda $S-189$, detail v severní části, zazděný gotický stavební článek.

Abb. 6. Prag - Vyšehrad. Sondierschnitt S-189, Detail im Nordteil, vermauertes gotisches Bauelement.
V návaznosti na tuto problematiku požádala vyšehradská kapitula pisánského arcibiskupa Mons. Giovanniho Paola Benotta, aby jí věnoval malý zlomek $\mathrm{z}$ původního oltáře, který je dnes uložen v Muzeu pisánského dómu. Jednání bylo pozitivní a jeho výsledkem bylo získání relikvie, jež byla při slavnostní mši 14. března $2010 \mathrm{v}$ dómu v Pise převzata vyšehradským kanovníkem a děkanem Katolické teologické fakulty Univerzity Karlovy v Praze ThDr. Prokopem Brožem. Dne 20. listopadu 2010 byla slavnostně uložena do hlavního oltáře na Vyšehradě. Jejím získáním navázala vyšehradská kapitula na tradici a své exemptní postavení v době Karla IV.

\section{Reliéfní medailon}

V severní lodi kapitulního kostela byl při archeologickém výzkumu v roce 1984 v sektoru S-198 (ve východním profilu - řez 292) v zasypané sídlištní jámě nalezen kruhový medailon s motivem orla (?), vyrobený ze zvířecí kosti (průměr $43 \mathrm{~mm}$, výška $10-12 \mathrm{~mm}$ ). Podle určení L. Peškeho (z ARÚ AV ČR) je použitým materiálem paroží jelena. Datování podle stratigrafie není určující, nebot' materiál v zásypu byl různorodý. Nálezy tohoto druhu - zhotovené z kosti - jsou v našich podmínkách při archeologických výzkumech poměrně vzácné (Hrubý 1957; Kavánová 1995).

Popis nálezu: Kruhový medailon, ohraničený na obvodu dvěma výraznými reliéfními linkami, z nichž je vnitřní robustnější. Větší část plochy kruhu zaplňuje vkomponované okřídlené zvíre, pravděpodobně orel. Hlava s robustním krkem má zvýrazněné kruhové oko a ostrý zobák směřující vzhůru. Tělo $\mathrm{s}$ dvěma rozvinutými křídly je dole zakončeno poměrně krátkýma nohama a výraznými pařáty. Křídlo na pravé straně zvířete je heraldicky níže a na konci projmuto pěti zářezy. Druhé kř́ídlo je kolmo vztyčené a špičatě zakončené. Zde je naznačeno pouze schematicky silnější středové projmutí. Zadní strana je hladká a nezdobená. Medailon nenese stopy po funkčním upevnění.

Figura na medailonu má charakter spíše znakového vyjádření než reálného zpodobnění zvířete. Jde o určitý slohový princip, jak jej známe např́klad z vyšehradských dlaždic 


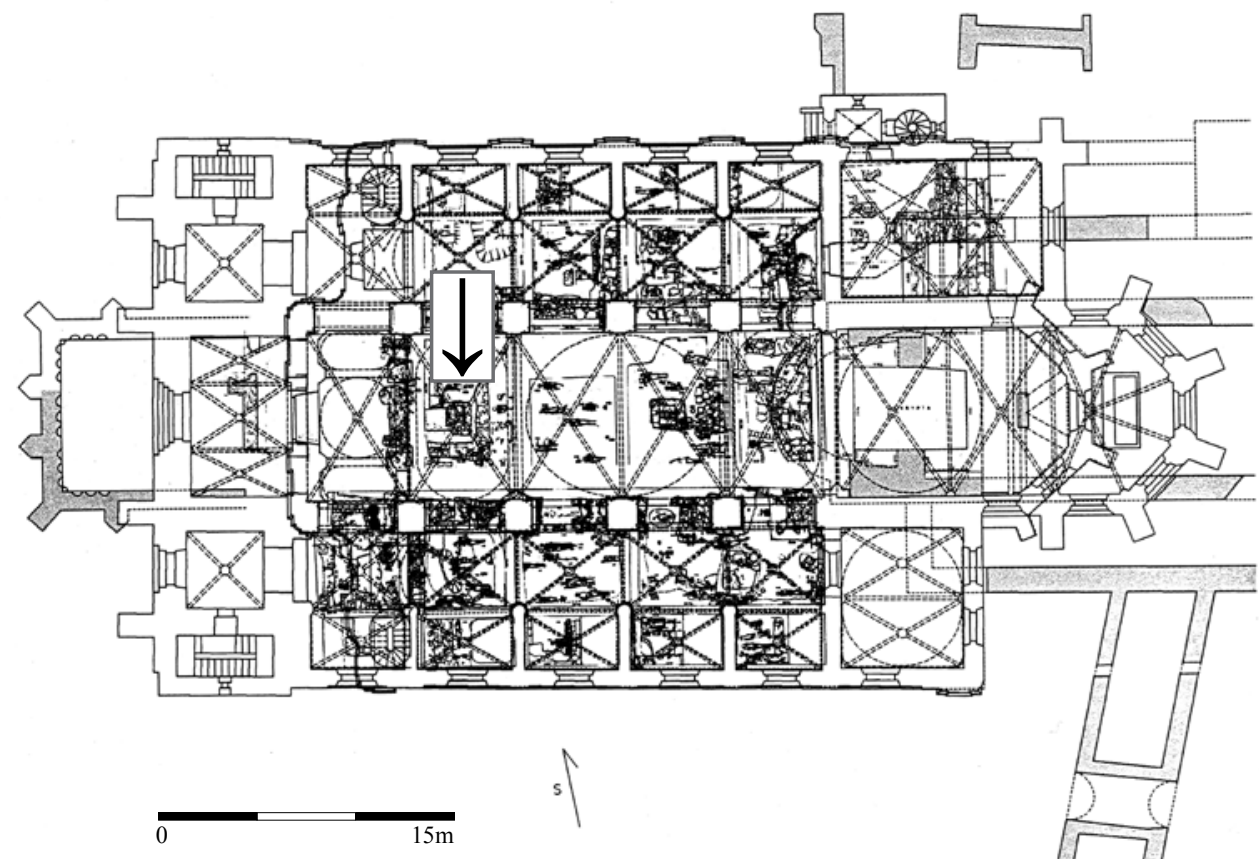

Obr. 7. Praha - Vyšehrad. Kapitulní chrám sv. Petra a Pavla s vyznačením archeologických nálezů, šipkou označen předpokládaný oltář sv. Petra. Podle Soukupová 2012.

Abb. 7. Prag - Vyšehrad. Kapitelkirche St. Peter und Paul mit eingezeichneten archäologischen Funden, der schwarze Pfeil kennzeichnet den mutmaßlichen Petrusaltar. Nach Soukupová 2012.

z baziliky sv. Vavřince na Vyšehradě, datovaných do poslední třetiny 11. století (Hejdová-Nechvátal 1970).

Nálezové okolnosti nejsou přesvědčivé, a proto se pokusíme o zařazení na základě ikonografického srovnání. Svatý Jan Evangelista bývá jako nejpřednější z evangelistů spojován s orlem v biblických textech. Jako nejbližší ikonografický pramen se nabízí evangelistár̆ zv. Kodex vyšehradský (Codex Vysehradensis 1970; Otevři zahradu rajskou 2014), spojovaný s první královskou korunovací v Čechách, datovaný k roku 1085. V úvodní partii na fol. 1 jsou v kruhových medailonech všichni evangelisté se svými symboly (Jan, Lukáš, Marek, Matouš). Jan je umístěn nejvýše v ose obrazu. Má nad hlavou znakový symbol orla. Je zpodobněn v klidném a vážném majestátu.

Motiv evangelistů je také uplatněn na další archeologické památce, na ostatkovém křížku z Vyšehradu, který byl nalezen v roce 1884 ve východní části hřbitova při výkopu hrobu B. Smetany. Až do těchto míst dosahovalo raně středověké pohřebiště. Kř́žek s motivem Panny Marie jako orantky, jenž je v našich nálezech motivem ojedinělým, má přímé analogie v Kyjevě v široké kulturní oblasti byzantsko-kyjevské. Je vzácným dokladem česko-ruských, vlastně východních styků 10.-12. století. Zjišt’ujeme je sporadicky v hmotné kultuře našich zemí (Nechvátal 1979, 213-251). Evangelisté jsou zde vyobrazeni v obrysových plaketkách hlavy s horní částí těla bez dalších atributů. Poměrně blíže se medailonu podobá další vyobrazení z vyšehradského korunovačního kodexu na fol. $9 \mathrm{v}$, kde je Kristus vyobrazen v mandorle. Je nadnášen anděly v křížovém uspořádání se znaky jednotlivých evangelistů. Na čestném nejhořejším místě směřujícím vzhůru je orel - znakové označení sv. Jana Evangelisty. V mnohém se podobá vyobrazení dravce na našem medailonu. Stejná stylizace hlavy se zobcem a rozevřená kř́idla s pařáty. Kompozice je po ideové stránce rovněž velmi blízká. 


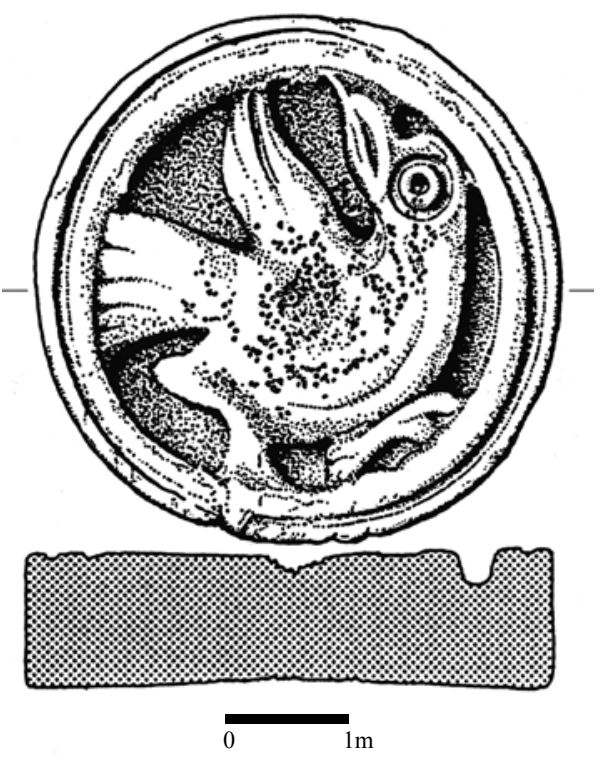

Obr. 8. Praha - Vyšehrad. Reliéfní medailon s motivem orla (?) nalezený $v$ interiéru baziliky při archeologickém výzkumu v sektoru S-198. Kresba J. Steklá.

Abb. 8. Prag - Vyšehrad. Im Innern der Basilika bei einer archäologischen Grabung in Sektor S-198 entdecktes Reliefmedaillon mit Adlermotiv (?). Zeichnung J. Steklá.

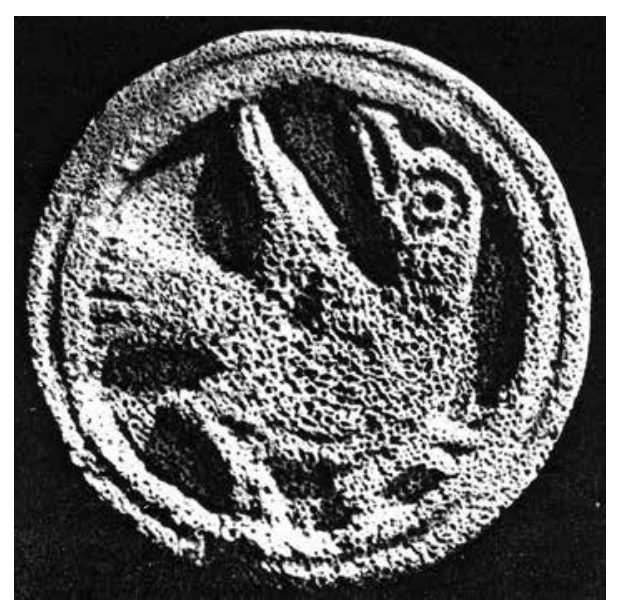

Obr. 9. Praha - Vyšehrad. Reliéfní medailon s motivem orla (?) ze sektoru S-198. Foto H. Toušková.

Abb. 9. Prag - Vyšehrad. Reliefmedaillon mit Adlermotiv (?) aus Sektor S-198. Foto H. Toušková.
Symbol orla je znám již jako předkřest’anský. Setkáváme se s ním např. ve Starém zákoně v knize Ezechiel, v úvodní partii, když je Ezechiel povolán za proroka (Bible, 671). Zvláštní postavení má potom motiv orla především v Novém zákoně - Zjevení svatého Jana - část 4. Vidění boží moci (Bible, 968). Zde je jeho výsostné postavení podáno jako jeden ze čtyř symbolů. Bylo by jistě možné dále sledovat atribut orla jako symbol evangelisty sv. Jana a z početných pramenů domácí a hlavně cizí literatury např. jako výsostný symbol ř́iší a států již od starověku. Pro další interpretaci medailonu to však nemá podstatnější význam.

Pro nejstarší období je na Vyšehradě doložen kostel s patrociniem svatého Jana Evangelisty. Je uváděn jako ,in curia regis“ v okrsku krále - a jeho podoba je označována jako „capella rotunda“. Další důležitou skutečností je zjištění, které učinila J. Hásková při rozboru denárů z vyšehradské mincovny pro nejstarší období - EAN, IAN nebo IEAN je ve staroslověnské formě označení pro jméno Jan. Tyto denáry byly vyšehradskou mincovnou vydávány kolem roku 1000. Není zcela vyloučeno, že toto označení má spojitost se zasvěcením rotundy svatého Jana Evangelisty (Hásková 1975, 105n). Její poloha, ani podoba nejsou zatím po archeologickém výzkumu známy. Pro důkaz stáŕí kostelíka sv. Jana Evangelisty bývá uváděn text listin pražského biskupa Jana III. z Dražic z let 1258-1264. Stavební stav kostela byl v tomto období špatný a potřeboval velkou opravu, kterou byl pověřen správce kostela sv. Štěpána na Zlíchově, kanovník Bartoloměj. Dostal povolení přenést zasvěcení sv. Štěpána a sv. Gereona a jeho druhů i s ostatky ze Zlíchova do kaple sv. Jana Evangelisty na Vyšehrad. V době přenesení zjistil biskup Jan III. z Dražic staré známky „verissimis argumentis“, že kapli kdysi světil sv. Vojtěch. Nemohlo jít o autentiku, nebot' ta je doložena až z pozdější doby, $\mathrm{z}$ období biskupa Daniela (1148-1167; Pavlíková 1952, 4-5). O této kapli byla patrně zmínka v polo-

vině 13. století, i když bez uvedení patrocinia, jako „capella nostra specialis“, jak na ni v jiné souvislosti upozornil P. Sommer při interpretaci církevní terminologie sakrálních objektů (1982, 458-459). V období 13. a 14. století je termín „capella nostra specialis“ použíán pro název Královské kolegiátní kapituly sv. Petra a Pavla v celé řadě královských listin.

Původní funkci medailonu neznáme, jeho tvarová podoba není spolehlivým vodítkem pro interpretaci. A. Merhautová uvažovala, že by mohlo jít i o hrací kostku (osobní sdělení A. M.). 
Uplatnění motivu na textilní nášivce, např. doložené v Litvě, není motivem nejjistějším (Mugurevič 1965, tab. XIV - srov. též motiv dravého ptáka na dně bronzové mísy - tab. XXVII). Také se soudilo, že medailon mohl být vsazen do kruhové objímky a použit na držadle hole, berle nebo jiné opěrky. Zvěrné motivy byly rozšířeny v raně středověkém období také na hracích kostkách aj. Nověji navrhuje H. Soukupová, že může jít o figuru šachové hry (Soukupová 2005, 210).

Kulturní oblast, odkud pochází medailon s motivem orla, je obtížné zjistit. Výrobky uměleckého řemesla tohoto druhu se pravděpodobně vyskytovaly po celé období raného středověku. Není vyloučeno, že kromě importu mohly být u nás také vyráběny. V nejednom případě, jak bylo prokázáno při analýze medailonu oběti Abrahámovy z Vyšehradu, byla slonovina, v domácím prostředí nedostupná, nahrazena mastkem (Nechvátal 1970, 319n). Výrobky z kosti se dochovaly v omezené míře. Jsou to převážně slovanské mladohradištní hřebeny, jejichž obě strany bývají ornamentálně zdobeny. Ve výzdobných motivech převažuje zalamovaná páska, prolamovaný ornament a motiv soustředných kroužků, tzv. očka. S některými se setkáváme již v době římské a v období stěhování národů.

Drobná zmínka o nich je v Kosmově kronice, v pasáži o zavraždění synů Mutinových (FRB II, 161 - „Quid autem referam de morte natorum Mutinae, quorum mors visa est omni
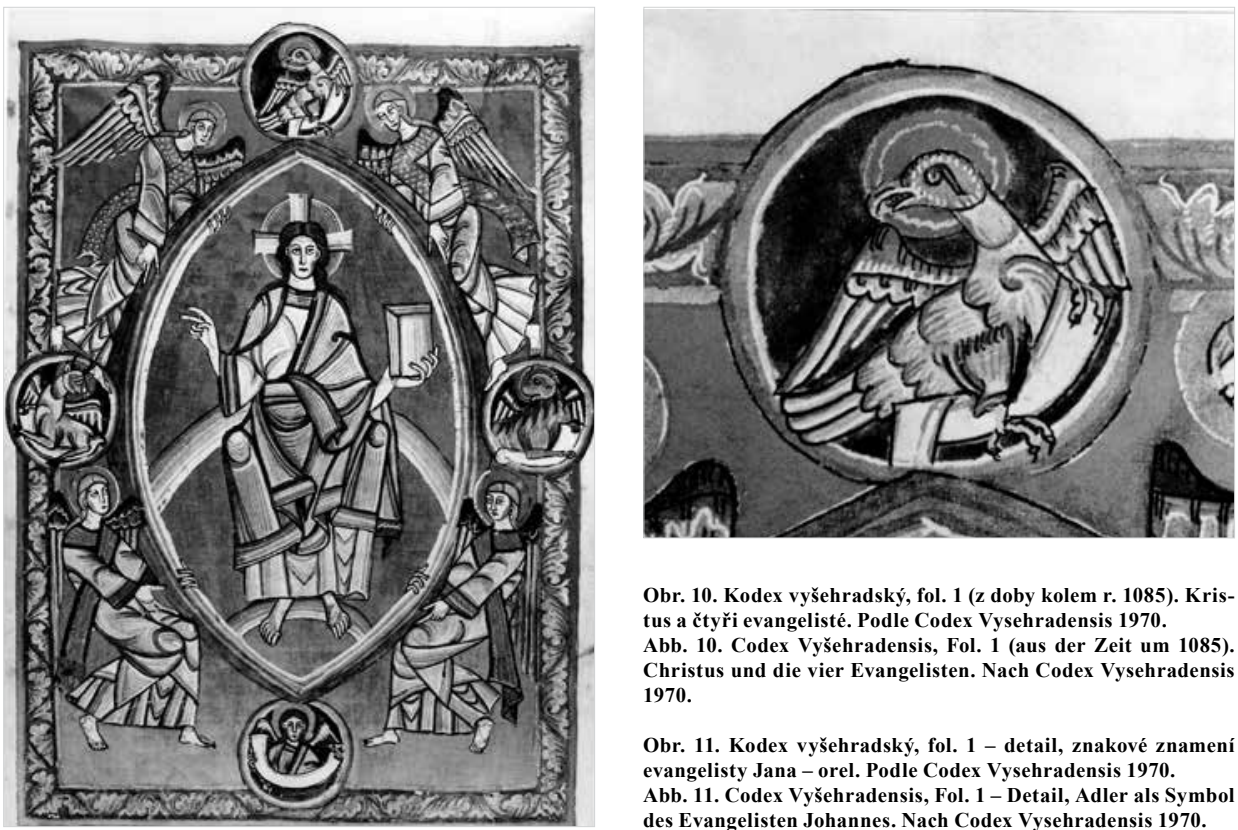

Obr. 10. Kodex vyšehradský, fol. 1 (z doby kolem r. 1085). Kristus a čtyři evangelisté. Podle Codex Vysehradensis 1970.

Abb. 10. Codex Vyšehradensis, Fol. 1 (aus der Zeit um 1085). Christus und die vier Evangelisten. Nach Codex Vysehradensis 1970.

Obr. 11. Kodex vyšehradský, fol. 1 - detail, znakové znamení evangelisty Jana - orel. Podle Codex Vysehradensis 1970. Abb. 11. Codex Vyšehradensis, Fol. 1 - Detail, Adler als Symbol des Evangelisten Johannes. Nach Codex Vysehradensis 1970.

crudelior morte? Erant enim bonae indolis pueruli, vultus spectabilis, visu amabiles, guales nec sagax artifex in albo ebore nec pictor in pariete valet exprimera."). Jejich krása je přirovnávána k plastice ze slonoviny; je zde tedy doklad, že tyto výrobky byly známy i v našem prostředí. Bylo upozorněno na některé souvislosti, s kterými je nutno počítat při jejich interpretaci. Jde o nálezy skutečně vzácné a zcela ojedinělé.

\section{Kruhová stavba}

V roce 1983 byla při archeologickém výzkumu v interiéru kapitulního kostela v dnešní lodi (v sektoru S-187) před západním závěrem raně středověké baziliky zjištěna kruhová stavba. Již v předběžné zprávě o výzkumu byla interpretována jako baptisterium (Nechvátal 1985, 142). Její poloha je téměř v ose západního závěru raně románské baziliky, s menší odchylkou k jihu. Je 
vzdálena západním směrem $310 \mathrm{~cm}$ od hrany zdiva baziliky, v hloubce $220-240 \mathrm{~cm}$ pod povrchem původní teracové podlahy. Kruhová stavba je kamenná, vytvořená ze štípaných plochých opukových desek a kamenů. Její zásyp byl proveden hlinitým až jílovitým materiálem podloží. Je rezavě hnědého zbarvení, promíšen sídlištním mastným černošedým materiálem. Byl přemístěn do zásypu při úpravě a rozšiřování raně středověkého pohřebiště, které obklopovalo raně středověkou baziliku ze tř́i stran, ze čtvrté, jižní strany byl prŕíkop s tzv. románským mostem. Spojoval ji s knížecí a královskou akropolí. Na severní straně byl kapitulní dům, který byl zčásti zjištěn při archeologickém výzkumu. V zásypu stavby byla celá řada zlomků raně středověké keramiky a také nádob, které jsou stratigraficky datovány do doby kolem roku 1070, tedy do doby postavení raně románské baziliky. Datum stavby je spolehlivě doloženo písemnými prameny. Rozpětí datování zásypu stavby je dáno nálezem denáru Vratislava II. (1061-1092) z období knížecí vlády 1061-1085 až z období před 1129, kdy došlo k stavební úpravě za Soběslava I. (1125-1140).

Kruhová stavba má průměr $87-90 \mathrm{~cm}$, šiřka ústí dosahuje na severní straně hloubky $134 \mathrm{~cm}$ od povrchu stavby. Zachovaná část je založena do rostlého terénu, do rezavě jílovitě hlinitého podloží. Profil zdiva se mírně kónicky zužuje ke dnu a dno je užší téměř o třetinu, jeho průměr má pouhých $67 \mathrm{~cm}$, je dlážděno menšími nepravidelnými opukovými kameny. Vlastní kamenná stavba jeho průměr má na severní straně zachováno 14 řad zdiva z lomové opuky nepravidelného, lomového charakteru. Zdivo je zděno na hlínu s nepravidelnou lící, místy vyhřezlou. Ve směru k západní apsidě je v horních partiích (poslední 2-3 řady) uloženo na vápennou hrubozrnnou maltu. Zdivo je zapuštěno do rostlého terénu. Průměrná výška kamenů nepřesahuje většinou $10 \mathrm{~cm}$, ojediněle má $15 \mathrm{~cm}$. Jižní strana stavby je poškozena, stejně jako strana západní dosahuje

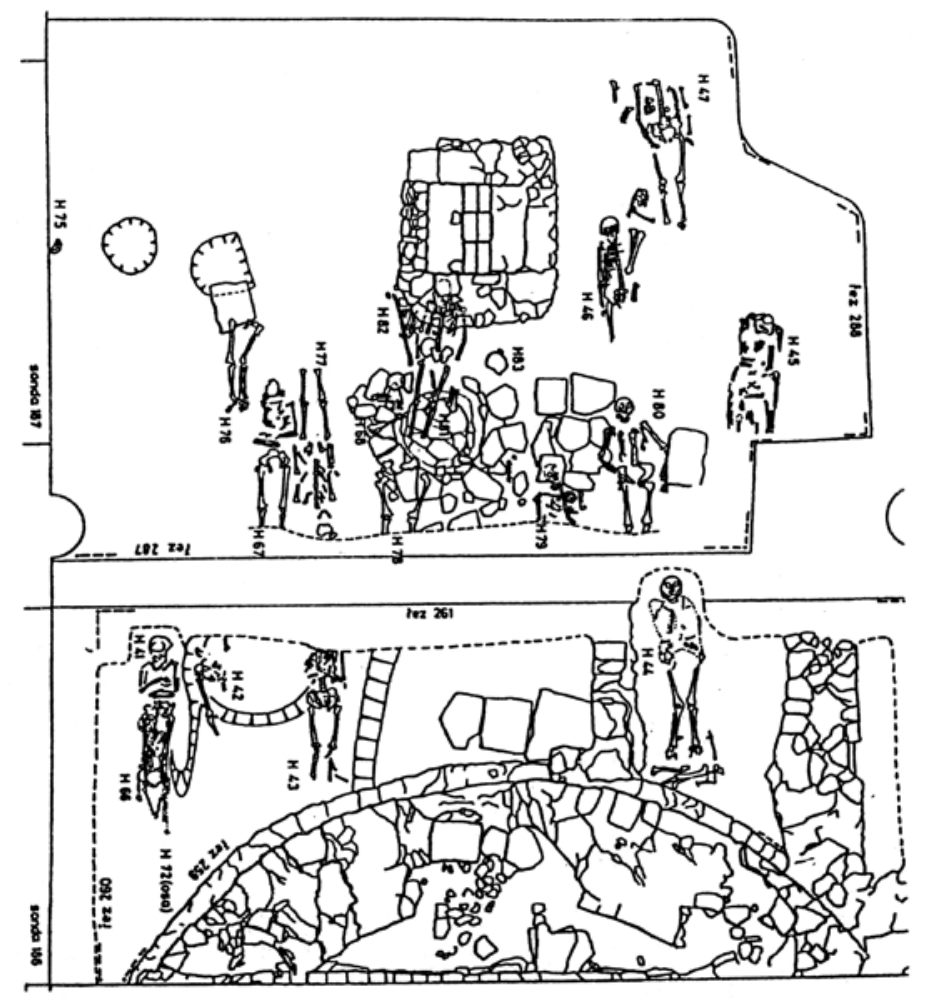

Obr. 12. Praha - Vyšehrad. Archeologický výzkum v interiéru baziliky sv. Petra a Pavla, sektor S-187, S-186. Abb. 12. Prag - Vyšehrad. Archäologische Grabung im Innern der Peter-und-Paul-Basilika, Sektor S-187, S-186. 
pouze $104 \mathrm{~cm}$. Kruhová stavba je podobně jako obdélná stavba na západní straně, která je v ose raně stř̌edověké baziliky, překryta dolními končetinami hrobu č. 81 a také hrobem č. 82 . Zčásti je také kruhová stavba překryta hrobem č. 68 a rozrušeným hrobem č. 78 (při severním okraji stavby) mezi hroby č. 81 a 78 (na jižní straně) a hrobem č. 79, který byl v blízkosti rozrušeného hrobu č. 83 , z něhož byla zachována pouze lebka. Hroby jsou uloženy v rostlém terénu bez milodarů ještě s mladohradištním pohřebním ritem bez nálezů - ruce volně podél těla. Nejsou zde stopy kamenného obložení nebo jiné úpravy hrobů (např. dřevo). V druhotné poloze na severní straně kruhové stavby byl denár z období knížecí vlády (1061-1085) Vratislava II. (1061-1092), typ III. (Cach 347). Poloha denáru je označena na obr. 13 značkou X. Tento typ J. Hásková klade do 60. let 11. století $(1992,61)$.

I když je nález denáru v druhotné poloze, poměrně přesně datuje uložení hrobů a pravděpodobný vznik kruhové stavby. Vyjdeme-li z charakteristiky a datovací schopnosti obolu mrtvých, jak určuje P. Radoměrský (1955) a J. Klápště (1999), je uložení denáru datováno lety 1061-1086 do období knížecí vlády Vratislava II. a také do doby vzniku kapitulního kostela, který byl založen kolem roku 1070. Královská korunovace byla v roce 1085, respektive 1086, tedy jde o období pouhých patnácti nebo šestnácti let.

Při sledování terénní situace jsou patrny na severní straně kruhové stavby větší ploché kameny, které zdánlivě vytváŕejí a vymezují šířku zdi. Ve skutečnosti jsou tyto kameny uloženy pod hrobem č. 79, který je vlastně na nich položen, především v partii hlavy. Zčásti jsou podloženy pod pravou horní končetinou od hrobu č. 80, v západovýchodní orientaci. Pravá ruka je uložena na pravé straně pánevní kosti a levá uvolněná, lehce vzdálena od trupu, a poloha je vymezena opukovou deskou. Tyto volně řazené kameny souvisí patrně s destrukcí kruhového útvaru a kumulují se, jak uvedeno, na jeho severní a zčásti na východní straně. Kruhový útvar skončil svou funkci zasypáním a uložením hrobů č. 81, 82, 68, 78, 79 a 80 . Objekt o čtvercovém půdorysu mezi hroby č. 46 (na severní straně) a č. 82 na jihozápadní straně, kterým je částečně

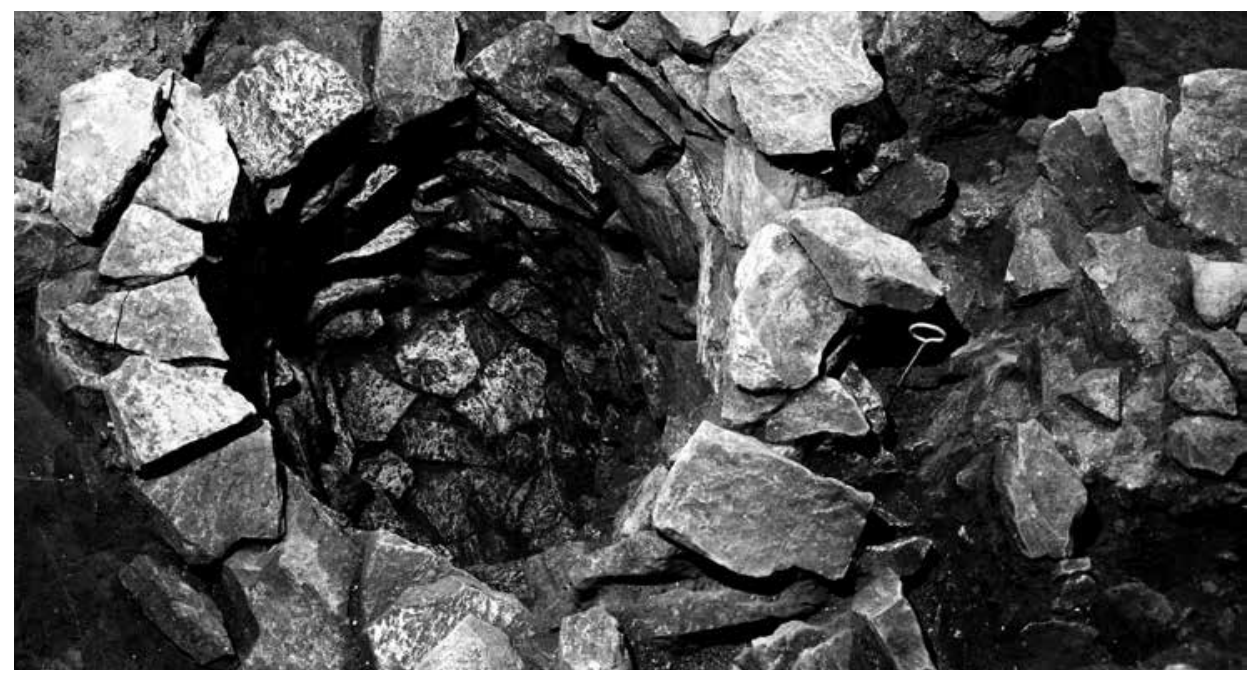

Obr. 13. Praha - Vyšehrad. Základy kruhové stavby baptisteria v sektoru S-187 v pohledu od východu. Bílá jehla označuje nález denáru. Foto J. Král.

Abb. 13. Prag - Vyšehrad. Fundament des runden Baptisteriums in Sektor S-187 von Osten. Die weiße Nadel kennzeichnet die Fundstelle eines Denars. Foto J. Král.

překryt, byl považován za mladší. V jeho zazdívce je uloženo šest cihel. Poloha útvaru v ose baziliky je jistě významná, ale interpretaci není možno spolehlivě rozhodnout. Jeho jihozápadní a jihovýchodní nároží překrývá hrob č. 82, který dolními končetinami přesahuje přes kruhový útvar. To určuje časovou následnost. Hrob je s uvolněným hradištním pohřebním ritem, s horní- 
mi končetinami volně podél těla. Překrytí čtvercového objektu naznačuje časovou souslednost. Symetrické rozdělení na dvě poloviny šesti cihlami se stopami lomových kamenů různě zapuštěných pod jejich úrovní do rostlého podloží neumožňuje jeho jednoznačnou funkční interpretaci.

Funkční ukončení kruhového útvaru nemůžeme blíže stanovit, není vyloučeno, že svůj význam mělo narůstání hřbitova. Na severní straně je ukončen kapitulním domem a na jihu př́íkopem s románským mostem, který spojoval komplex kapitulního kostela s knížecí a královskou akropolí. Vzdálenost hlavní lodi raně románské baziliky (pouhých $310 \mathrm{~cm}$ od kruhové stavby) vedla patně k tomu, že při druhé etapě přestavby románské baziliky za Soběslava I. (1125-1140) došlo před rokem 1129 z důvodů komunikačních patrně ke zrušení funkce kruhového útvaru a jeho přeložení na jiné místo.

V písemných pramenech je sice uveden charakter přestavby baziliky (FRB II, 206; CDB I, 112 č. 111), ale nelze ji podrobněji specifikovat jako příspěvek k horizontální stratigrafii uvnitř interiéru kapitulního kostela, ani jako př́íspěvek k chronologii Vyšehradu.

Sledujeme-li osy hrobů č. 67 a 80, vymezují jednu hrobovou řadu. Totéž platí i u os hrobů č. 46 a 76. Hrob č. 81 porušuje tyto řady a byl patrně uložen jako mladší, možná jako nejmladší. Při jeho uložení do země došlo k porušení starších hrobů, jejichž pozůstatky byly potom uloženy jako příměs (srov. antropologický rozbor P. Stránské). Raně středověké mladohradištní pohřebi-

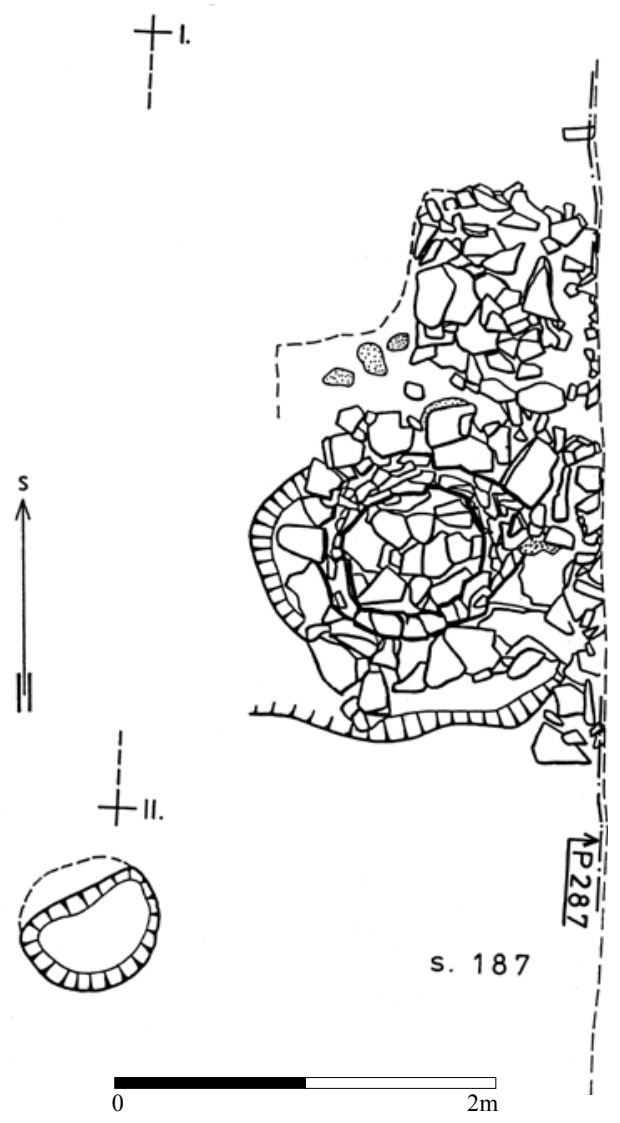

Obr. 14. Praha - Vyšehrad. Sonda S-187, půdorys kruhové stavby - baptisteria po vyzvednutí hrobů a začistění.

Abb. 14. Prag - Vyšehrad. Sondierschnitt S-187, Grundriss des runden Baptisteriums nach Hebung der Gräber und nach Beräumung. ště u vyšehradského kapitulního kostela je dochováno ve zcela torzálním stavu. Je porušeno mladšími hroby, což bylo kromě jiného způsobeno omezeným prostorem určeným k pohřbívání. Přesto je cenným svědectvím soudobého pohřebního ritu s převažujícím typem rukou podél těla a absolutní absencí milodarů.

Kruhová stavba a její interpretace mají význam pro liturgickou praxi v prvém období dějin kapitulního kostela. S podobnými stavbami různé topografické polohy a velikosti, interpretovanými jako baptisteria, se setkáváme u celé řady velkomoravských bazilik. Baptisteria sloužila při křtu a měla skutečně významný podíl při vstupu nového katechumena do církve. U velkomoravských kostelů je patrno, že jejich poloha nebyla ustálena. Současná archeologická literatura upozorňuje na kostely vybavené baptisterii (KouřilMěřínský 1996, 113) a hodnotí jejich význam (především III. a IX. kostel $\mathrm{v}$ Mikulčicích a Sady u Uherského Hradiště - srov. též Poulík 1975, 115-116). Sehrály nesporně důležitou úlohu v organizaci církve na Moravě, mohlo jít někdy o biskupská sídla. Interpretace stupňovitých útvarů jako baptisterií musí být $\mathrm{v}$ budoucnu podrobena dalšímu kritickému zkoumání. Neodpovídají vždy kritériím pro baptisteria, jak jsou známa např. v italském prostředí. Ve velkomoravském období se problematikou křtu s některými křestními objekty po stránce teologické interpretace a vývoje v přemyslovských Čechách zabýval L. Pokorný ve své přehledné práci (1982). Jeho dedukce teologického a historického vývoje inspirují 


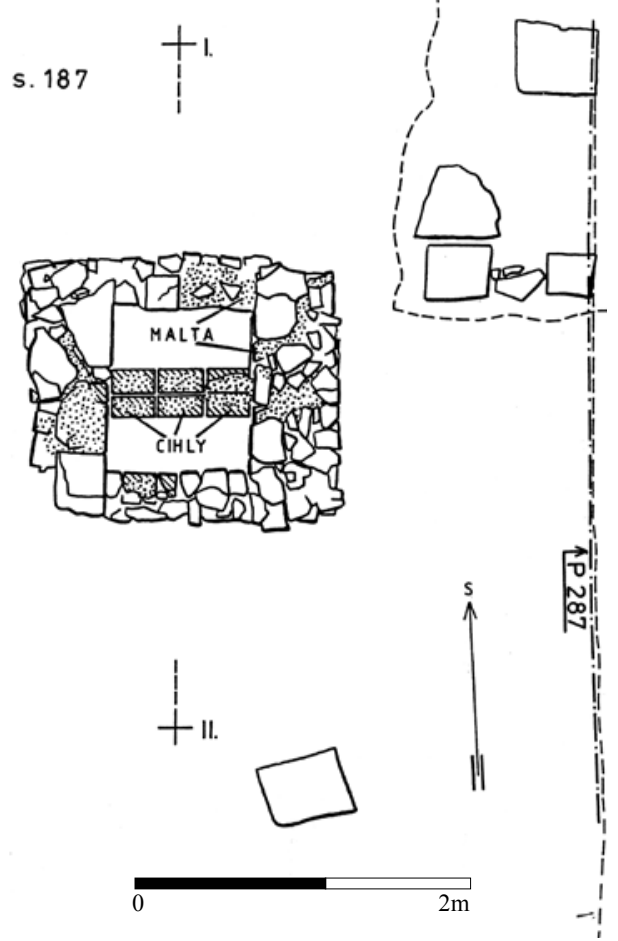

Obr. 15. Praha - Vyšehrad. Sonda S-187, půdorys čtvercového kamenného objektu, chronologicky a funkěně neurčeno.

Abb. 15. Prag - Vyšehrad. Sondierschnitt S-187, Grundriss eines viereckigen Steinobjektes, chronologisch und funktionsmäBig unbestimmt. k dalšímu sledování. Soustavněji přinesl tuto problematiku do české archeologické literatury jako první I. Borkovský v souvislosti s problematikou nálezu pisciny ve tvaru kř́že, při jeho archeologickém výzkumu svatojiřského kláštera na Pražském hradě z 10. století. Byli zde také pochováváni Přemyslovci (Borkovský 1960, 680-691, 691-705; 1975, 28-32). Interpretace zahloubeného křestního útvaru ve tvaru kříže nedošla všeobecné shody (Fehring-Stachel 1966), někdy se také uvažuje o tom, zda nejde o relikviářový hrob (Turek 1988, 155). Za piscinu, která byla určena ke křtu, je někdy považována vyhloubená nádrž ve tvaru kř́že i v baptisteriu u kostela sv. Klimenta v Ochridu z 9. století (Šolle 1996, 68). Podle Z. Váni (osobní sdělení) lze za piscinu sloužící ke křtu považovat úzký protáhlý vyhloubený objekt za budečskou rotundou. Z dalších převážně mladších objektů, které sloužily jako křestní, je považován jako nesporný nález v klášteře Ostrov u Davle na soutoku Sázavy a Vltavy (dle sdělení M. Richtra).

V dnešní laické občanské společnosti je nesporným přínosem, že hlavní církve působící v českých zemích - především církev římskokatolická, evangelická a československá husitská - navzájem uznaly platnost svých obřadů. Stará křest’anská tradice se na základě Písma svatého jednoznačně shoduje v tom, že křest byl od počátku důležitou změnou myš-

lení a ovlivněním dalšího života. Písmem svatým je tato výrazná změna nazývána „metanoia“. Křest je chápán jako včlenění jedince do společenství víry a nabývání základního vztahu k Ježíši Kristu. Přijímáním Ducha svatého je symbolicky odpouštěn dědičný hřích. Člověk jako jedinec vstupuje do intenzivního a vzrušujícího napětí možnosti své budoucí záchrany a možnosti na ní spolupracovat. Na základě textu Nového zákona je křest jednou ze svátostí, které ustanovil Ježíš Kristus. Sám název pro křest „regeneratio“ je chápán jako znovuzrození ve smyslu slov Ježíše Krista: „Nenarodí-li se kdo z vody a Ducha, nemůže vejít do Božího královstvi““ (Jan, 3, 5). Prvotní křest’ané, ale i pozdější stavěli životu křest’ana jako protiklad život pohana, protože se navzájem odlišují orientací k věčnému životu. Křest je zprostředkován vnějším znamením, mimořádný význam má myšlenka omývání - tedy čistoty (Kadlec 1993; Šolle 1996).

První křty byly prováděny př́rodní vodou. Byla vybírána místa, kde se dalo křtít v tekoucí vodě. Postupný rozvoj křest’anství a jeho šíření v hustěji zalidněných městských aglomeracích vedl k praxi, že křest ve volné př́rodě zanikl. Nadále však zůstává snaha ponechat místo křtu $\mathrm{v}$ její blízkosti. Je doloženo, že se křest také udílel v atriích domů, kde byla př́istupná nádrž na deštovou vodu.

Teprve až po roce 313 (po vydání ediktu milánského) se začala zřizovat baptisteria. Byla zpočátku u biskupských kostelů, které měly právo křtu. Na ostatní kostely, především venkovské, přechází později. Předpokládá se, že asi v průběhu 6. století.

Nejstarší baptisteria byly stavby vybavené piscinou. Byl to jakýsi bazén, kam vedly schody z obou stran. Mezi nejstaršími je uváděno baptisterium ve městě Dura Europos v Sýrii, na středním Eufratu. Pisciny byly většinou relativně mělké, jak ukazují zachovaná baptisteria. Pro 

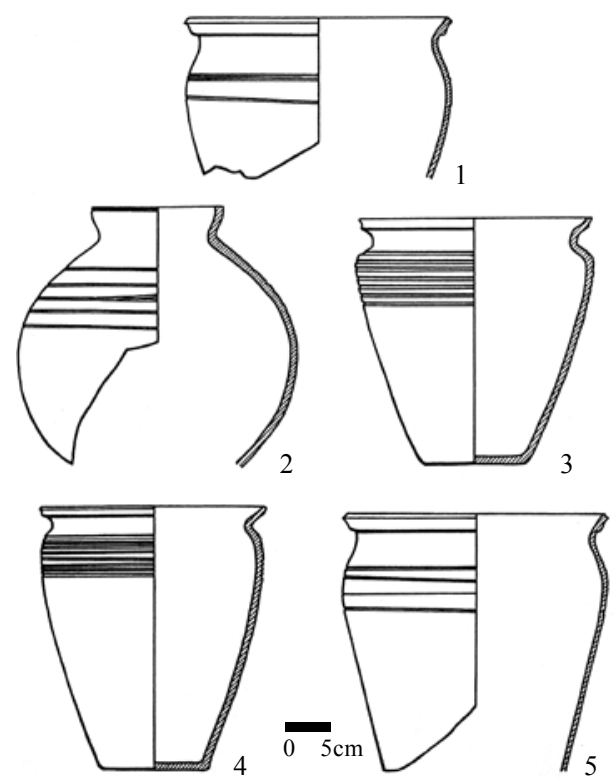

Obr. 16. Praha - Vyšehrad. Raně středověká keramika ze zásypu výplně kruhové stavby - baptisteria z období okolo 1070 až z období před 1129. Sáček č. 17/1984. Kresba O. Tomášková. Abb. 16. Prag - Vyšehrad. Frühmittelalterliche Keramik aus der Verfüllung des runden Baptisteriums aus dem Zeitraum um 1070 bis vor 1129. Tüte Nr. 17/1984. Zeichnung O. Tomášková. hlásili. Lidé vyčkávali se křtem co nejdéle, někteří až do smrtelného lože. Právě ze 3 . století jsou doloženy podmínky, které dokazují určitou přísnost při přijímání do katechumenátu. Jestliže některý kandidát nepocházel z křest’anské rodiny, bylo třeba, aby byl k představeným obce přiveden a doporučen některým osvědčeným křest’anem. V př́ípadě křtu otroka, který měl za pána křest’ana, bylo požadováno prohlášení pána, že se otrok dobře choval. Délka katechumenátu zpravidla trvala tři roky. V případě obzvláštní horlivosti mohla být doba zkrácena, končila zkouškou. Nevěnovala se tolik vědomostem, ale byla zkouškou chování a života (Kadlec 1993; Šolle 1996).

Časově nebyla určena doba křtu, obecně bylo za nejvhodnější považováno období Velikonoc a svátky Ducha svatého. Nebylo výslovně určeno místo křtu, byla vybírána místa, kde se dalo křtít v tekoucí vodě.

Starší názor, že křest dětí byl zaveden až v 5. století, nebyl shledán přesným, bylo zjištěno, že byl praktikován již za Hippolita (175-235), doložen byl již v době starokřestanské. Rozšířní se postupně uskutečnilo během 5.-6. století, ovlivnilo vznik křtitelnic. Ty měly zpočátku podobu válcovitých nádob, do nichž se děti ponořovaly. Zachované nejstarší raně středověké křtitelnice jsou až z období románského umění, mají převážně podobu sudu nebo kotle. Některé byly různým způsobem výtvarně zdobeny. Později v pokročilém středověku, v gotickém období, dostávají křtitelnice podobu obráceného zvonu, který je postaven na nohách nebo na sloupku. Umístění víka na křtitelnici je prokazatelné až od 12. století. V nejednom případě byly křtitelnice uvnitř členěny. V jedné části se uchovávala křestní voda, druhá část byla prázdná a nad ní se křtilo, nádoba zachycovala stékající vodu a odváděla ji do sakrália.

Jak již bylo řečeno, první křest’anské křty byly prováděny prŕírodní vodou a dávala se přednost vodě tekoucí. Poměrně záhy byla použivána voda svěcená. Z východního křest’anství je mezi modlitbami biskupa Serafiona z Thunis († 362) prosba k Bohu, aby seslal Ducha svatého a propůjčil vodě nadpřirozené síly. 
Pojem kmotrů je znám již z doby starokřest’anské. Kmotry nebo učiteli mohli být křest’ané, kteří kandidáty doporučovali představenému obce. Jsou o nich zprávy již ve 2 . století, především $\mathrm{v}$ díle Tertuliánově. Týkalo se to především sirotků, kterým měli kmotři nahradit rodiče. Povinnost mít vlastního kmotra se vyvinula až mezi 5.-7. stoletím.

Pro interpretaci baptisteria má rozhodující význam charakter křestního úkonu. Podle dosavadních znalostí je pravděpodobné, že současně byl křest praktikován jako ponořování i jako lití vody na hlavu. Předpokládá se, že se užívaly kombinované formy - křtěnec stál ve vodě a na hlavu se mu lila voda. Katoličtí liturgičtí historikové potvrzují, že ponořování se rozšiřiilo v době, kdy nabyl převahy křest dětí. V době mezi 9. a 13. stoletím se ponořování stalo všeobecným (Pokorný 1982; Kadlec 1993; Šolle 1996). V průběhu 15. století je v západní části lití zcela rozšsiřené, proti východnímu ponořování dětí při křtu je celá řada výtek. Od 16. století je potom lití praktikováno všeobecně. Ve slovech udělovatele spočívá vlastní forma křtu. Pro platnost formy se vyžaduje vzývání tří božských osob a podle katolických teologů také označení křestního úkonu („N., já tě křtím ve jménu Otce i Syna i Ducha svatého“), jak je odůvodněno v evangeliu sv. Matouše 28, 19.

Účinky křtu udělují milost ospravedlnění, které po stránce negativní spočívá v odpouštění hříchů, po stránce pozitivní v obnovení a posvěcení vnitřního života. Křestní obřad nemůže být opakován. V př́ípadě mučedníků je možnost, že křest může být nahrazen křtem touhy a krve (Kadlec 1993; Šolle 1996). ${ }^{1}$

Stručný historický přehled byl potřebný k úvaze o významu a podobě kruhového útvaru před západní apsidou hlavní lodi raně románské baziliky sv. Petra a Pavla, založené prvním českým králem Vratislavem II. (1061-1092). Máme k dispozici celou řadu jak dokladů obrazových, tak také archeologických. Našemu objektu je nejblíže vyobrazení na miniatuře sakramentáře pocházejícího z kláštera ve Fuldě, kde je pochován sv. Bonifác. Světec křtí nějakého velmože ponořením do kruhového objektu, který vyčnívá nad terénem. Nelze určit, z jakého materiálu je objekt zhotoven, kresba je př́liš schematická. Obraz patří k památkám z 10.-11. století (Šolle 1996, 68-69). Sakramentář obsahuje liturgické knihy modliteb (např. mešních) užívaných v 6.-9. století.

Založeno na výsledcích grantového projektu Ministerstva kultury ČR a Archeologického ústavu ČR - „Kapitulní chrám sv. Petra a Pavla na Vyšehradě. Archeologický výzkum“ - PK 01 PO 40 PP 005-411.

\section{Prameny a literatura}

ARTEMIS, 1980: Lexikon des Mittelalters I. München - Zürich.

BENEŠOVSKÁ, K., 1991: Eliška Přemyslovna a Vyšehrad, Umění XXXIX, 214-232.

- 2001: Pramen ideální podoby kapitulního chrámu sv. Petra a Pavla - Eine Quelle zur ideellen Gestalt der

Kapitel-Kirche St. Peter und Paul. In: Královský Vyšehrad II, 90-101. Kostelní Vydří.

BIBLE, 1979: Písmo Svaté Starého a Nového zákona, ekumenický překlad. Praha.

BIRNBAUM, V., 1919: Stavební povaha nejstarších českých basilik, ČSPSČ XXVII, 1-22.

BORKOVSKÝ, I., 1960: Piscina ve tvaru kříže ve svatojiřské basilice na Pražském hradě - Piscine cruciforme dans la basilique St. Georges au chateau de Prague, AR XII, 680-691, 697-705.

BRETHOLZ, B., ed., 1923: Die Chronik der Böhmen des Cosmas von Prag. MGH SRG N. S. II. Berlin.

CACH, F., 1972: Nejstarší české mince (české a moravské denáry od mincovní reformy Břetislava I. do doby brakteatové), II. Praha.

CDB I: Codex diplomaticus et epistolaris regni Bohemiae I (Friedrich, G., ed.). Pragae 1904-1907.

CIBULKA, J., 1933: Václavova rotunda svatého Víta. In: Svatováclavský sborník I, 230-685. Praha.

CODEX VYSEHRADENSIS, 1970: Codex Vysehradensis Editio Cimelia Bohemica (Mašín, J., ed.). Praha.

ČAREK, J., 1947: Románská Praha. Praha.

1 Za pročtení odpovídajíćího textu a připomínky k významu křtu jsem zavázán díky emeritnímu děkanu Královské kolegiátní kapituly sv. Petra a Pavla na Vyšehradě prof. ThDr. J. Huberovi. 
DENKSTEIN, V., 1992: Někdejší vyšehradský lustr z r. 1129 (První středověký korunovační lustr zvaný „koruna“). In: Královský Vyšehrad I, 83-91. Praha.

ENCYKLOPEDIE ANTIKY: Encyklopedie antiky. Praha 1973.

FEHRING, P. G.-STACHEL, G., 1966: Kirchenanlagen, Herrensitz u. Siedlungsreste d. Mittelalters in Unterregenbach, Württembergisch Franken, Bd. 50, N. F. 40, 37-51.

FLOSSMANN, K., 1989: Moudrost ve Starém zákoně. Praha.

FRB II: Fontes rerum Bohemicarum II (Emler, J., ed.). Praha 1874.

HÁSKOVÁ, K., 1975: Vyšehradská mincovna na přelomu 10. a 11. století, SbNM XXIV, 105-160.

HEJDOVÁ, D.-NECHVÁTAL, B., 1970: Raně středověké dlaždice v Čechách - Frühmittelalterliche Fliesen in Böhmen, PA LVIII, 100-183, 395-471.

HRUBÝ, V., 1957: Slovanské kostěné předměty a jejich výroba na Moravě, PA XLIII, 118-217.

KADLEC, J., 1993: Dějiny katolické církve. I-III. Olomouc.

KAVÁNOVÁ, B., 1995: Knochen- und Geweihindustire in Mikulčice. In: Studien zum Burgwall von Milulčice I (Daim, F.-Poláček, L., edd.), 113-378. Brno.

KHATCHATRIAN, A., 1982: Origine et typologie des baptisteres paléochrétiens. Mulhouse.

KLÁPŠTĚ, J., 1999: Př́spěvek k archeologickému poznávání úlohy mince v přemyslovských Čechách - Ein Beitrag zur archäologischen Erforschung der Rolle der Münzen im Přemyslidischen Böhmen, AR LI, 774-808.

KOSMOVA KRONIKA: Kosmova kronika česká (Bláhová, M.-Fiala, Z., edd.). Praha 1975.

KOUŘIL, P.-MĚŘÍNSKÝ, Z., 1996: Sakrální architektura a hmotné památky odrážející projevy duchovní kultury z moravských a slezských archeologických výzkumů - Sakralarchitektur und Denkmäler der Sachkultur - Widerspiegelung der Äußerungen der geistigen Kultur aus den mährischen und schlesischen archäologischen Ausgrabungen (Arbeitsthese), AH 21, 111-119.

KUPKOVÁ, J., 1996: Baptisterium a architektura českého středověku - Das Baptisterum und die Architektur des tschechischen Mittelalters, AH 21, 131-137.

MARIGNOLA, J., 1987: Kronika česká. In: Kroniky doby Karla IV., 445-524. Praha.

MENCL, V., 1971: Poklasická gotika jižní Francie a Švábska a její vztah ke gotice české, Umění XIX, $217-254$.

MONUMENTA VATICANA V/1-2: Monumenta Vaticana Res Getas Bohemicas Illustrantia V/1-2. Acta Urbani VI. et Bonifatii IX. pont. Rom. 1378-1396, 1397-1404 (Krofta, C., ed.). Prague 1903-1905.

MUGUREVIČ, E., 1965: Vostočnaja Latvija i sosednie zemli v X.-XIII. vv. Riga.

NECHVÁTAL, B., 1979: Frühmittelalterliche Reliquienkreuze aus Böhmen, PA LXIX, 213-251.

- 2004: Kapitulní chrám sv. Petra a Pavla na Vyšehradě. Archeologický výzkum - St. Peter und Paul Kollegiatkirche auf Vyšehrad. Archäologische Forschung. Praha.

OTEVŘI ZAHRADU RAJSKOU, 2014: Otevři zahradu rajskou. Benediktini v srdci Evropy (Foltýn, D.Klípa, J.-Mašková, P.-Sommer, P.-Vlnas, V., edd.), katalog výstavy. Praha.

PAVLÍKOVÁ, M., 1952: O oltářních autentikách biskupa Daniela I, Věstník KČSN, tř. filosoficko-historicko-filologická II, 2-21.

POKORNÝ, M., 1982: Dvě liturgická pojednání. Praha.

POULÍK, J., 1975: Mikulčice. Sídlo a pevnost knížat velkomoravských - Mikulčice. Sitz und Feste der grosssmährische Fürsten. Praha.

PRVNÍ POKRAČOVATELÉ KOSMOVI: První pokračovatelé Kosmovi. Praha 1950.

RADOMĚRSKÝ, P., 1955: Obol mrtvých u Slovanů v Čechách a na Moravě - The Dead-Obolus by the Slavs of Bohemia et Moravia, SbNM A IX, č. 2, 3-81, Tab. I-V, Mapa.

SODI, S., 2000: Basilica di San Pietro a Grado. Pisa.

SOMMER, P., 1982: K postihnutelnosti termínu ecclesia a capella v archeologických pramenech - Zur Erfaßbarkeit der Termini ecclesia und capella in archäologischen Quellen, AH 7, 453-469.

- 2001: Začátky křestanství v Čechách (Kapitoly z dějin raně středověké duchovní kultury). Praha.

SOUKUPOVÁ, H., 2005: K problematice Vyšehradu, PRP 12, č. 2, 3-54.

- 2012: Pisánský oltář apoštola Petra v chrámu sv. Petra a Pavla na Vyšehradě. In: Královský Vyšehrad IV, 166-179. Praha.

ŠOLLE, M., 1996: Od úsvitu křestanství k sv. Vojtěchu. Praha.

TOMEK, V. V., 1855-1901: Dějepis města Prahy, I.-XII. Praha. 2. vydání I.-VII. Praha 1882-1906.

TUREK, R., 1982: Čechy v raném středověku. Praha.

ZAVŘEL, J.-ŽÁČEK, V., 2012: Petrografický rozbor zlomku oltářní desky z kostela San Pietro a Grado v Pise. In: Královský Vyšehrad IV, 180-183. Praha. 


\section{Zusammenfassung}

\section{Zur Interpretation der archäologischen Untersuchung der St. Peter-und-Paul-Basilika auf dem Vyšehrad (Prager Hochburg)}

Im Jahre 1966 wurde am Nationalen Kulturdenkmal Vyšehrad mit einer neuen archäologischen Grabung begonnen, die auf Ersuchen des damaligen Oberbürgermeisters Ludvík Černý vom Institut für Archäologie der Tschechoslowakischen Akademie der Wissenschaften durchgeführt wurde und bis heute von der Akademie der Wissenschaften der Republik Tschechien weitergeführt wird. Sie erbrachte eine Fülle an grundlegenden Erkenntnissen, die einen wichtigen Beitrag zum Wissensstand über den mit der ältesten Geschichte Böhmens verbundenen, frühmittelalterlichen Burgwall darstellen. Mit der Untersuchung der Kapitelkirche St. Peter und Paul - der zweiten Hauptbasilika des Přemyslidenstaates - wurde im Jahr 1968 begonnen.

Bei einer Revision der Befundsituation und Überprüfung des Berichts des aufopfernden Heimatkundlers Stanislav Kř́źzek (1921-1985) und des Bildhauers und Sammlers Karel Vlačiha (18501932) wurde am Osttor des Friedhofs ein Mauerwerk aus Pläner entdeckt, das ursprünglich als Teil einer Kapelle angesehen wurde, die zu einer der mittelalterlichen Kanonikerresidenzen gehörte. Erst später, nachdem im östlichen Teil des Friedhofs und des Slavins sowie am mittleren Hauptweg Sondierschnitte gelegt wurden, hat man festgestellt, dass es sich um ein großes, unbekanntes Sakralobjekt handelt, dass dann im Zuge der im Bereich des Friedhofs nach Westen fortgesetzten Grabung eindeutig als St. Peter-und-Paul-Basilika identifiziert werden konnte. So ist es in den Jahren 1968-1991 nach und nach gelungen, unter den komplizierten Geländebedingungen des Vyšehrader Friedhofs den gesamten Grundriss freizulegen.

Nach Vorbereitungsarbeiten und einem Studium der schriftlichen Quellen und des ikonographischen Materials wurde in den Jahren 1981-1985/1986 mit Zustimmung der staatlichen Behörden und des Denkmalschutzamtes und vor allem des Eigentümers des Königlichen Kollegiatstifts St. Peter und Paul im Innern des Bauwerks eine Grabung durchgeführt. Während der Dauer der archäologischen Grabung wurde der liturgische Betrieb der Kapitelkirche niemals unterbrochen.

Es wurden zwei romanische Bauetappen festgestellt. Die erste aus der Gründungszeit der Kirche (um das Jahr 1070) durch den Herzog und ersten böhmischen König Vratislav II. (1061-1092). Die zweite Etappe begann laut den schriftlichen Quellen dann in der Zeit vor 1129 unter der Herrschaft seines Sohnes Soběslav I. (1125-1140). Der archäologischen Grabung nach zu urteilen wurde zunächst die romanische dreischiffige Basilika mit zwei Chören und den Maßen von ca. $53 \times 17 \mathrm{~m}$ errichtet. Im Osten wurde sie mit drei halbrunden Apsiden abgeschlossen, und an der Westseite ging das Hauptschiff in eine halbrunde Apsis über. Das Grundrisskonzept war ähnlich wie das der Spytihněv-Basilika auf der Prager Burg und ist in den Ländern Böhmens das zweite Beispiel für eine ähnliche Anlage. Das durch die Grabung vor der Westfassade entdeckte Baptisterium deutet auf eine solche liturgische Praxis der Taufe hin, wie wir es in Großmähren antreffen. Im Südschiff wurde in der ursprünglichen Geländesituation ein frühmittelalterlicher Sarkophag gefunden. Die Kirche enthielt auch eine Regentengruft, die sich gemäß der Interpretation der Grabungsergebnisse vor dem Hauptaltar an der Ostseite zwischen zwei Glockentürmen befand, was in schriftlichen Quellen aus dem Jahr 1349 in der Formulierung ,inter campanilia“ zum Ausdruck kommt. Die Lage der Krypta war weder während der Grabung, noch später zugänglich. In der Krypta wurden der Gründer der Kapitelkirche - der erste böhmische König Vratislav II. († 14. Januar 1092) - und all seine Nachfolger beigesetzt, die von diesem zweiten Zentrum des böhmischen Přemyslidenstaates aus fast bis Mitte des 12. Jahrhunderts regierten.

Weitere zwei Bauetappen waren gotisch. Die erste von ihnen begann nach 1249, als die Kirche während den Kämpfen zwischen König Wenzel und seinem Sohn Přemysl abbrannte. Danach beginnt eine allmähliche Wiederinstandsetzung und ein Umbau, der bis zum Beginn des 14. Jahrhunderts andauerte. Daran hatten Dekan Držislav und offenbar auch König Wenzels (1271-1305) unehelicher Sohn Jan III. Volek (Johann das Öchslein) sowie Elisabeth von Böhmen (1292-1330), die seine Stiefschwester und vor allem die letzte Přemyslidenkönigin und Mutter Karls IV. war, ihren Anteil. Elisabeth starb am 28. 9. 1330 - am Wenzelstag - auf dem Vyšehrad im Hause ihres Stiefbruders, dem Propst Jan III. Volek. Entsprechend den Ergebnissen der archäologischen Grabung wurde der frühgotische Umbau in die dreißiger Jahre des 14. Jahrhunderts datiert. Mit ihm wurde gleichzeitig sowohl 
an der Ostseite, als auch an der Westseite vor dem romanischen Dreischiff begonnen. Sein Umfang im westlichen Teil ist uns heute nicht mehr bekannt, obgleich eine tiefergehende analytische Grabung weitere wichtige Feststellungen liefern wird.

Die zweite gotische Etappe begann unter Karl IV. nach dem Jahr 1369. Sie hat einen hochgotischen Charakter und ist eine der sieben Bauetappen der Kapitelkirche, die durch die Grabung noch erforscht werden kann. Die Etappe wurde auf Anregung Karls IV. in Angriff genommen, der mit dieser neuen Stiftung an das ursprüngliche Bauvorhaben seiner Mutter anknüpfte. Der Umbau zur dreischiffigen, eigentlich fünfschiffigen Kirche nach Arras'schem Schema wurde mit aufeinanderfolgenden Seitenkapellen durchgeführt, die an die Seite der jeweiligen Schiffe gesetzt wurden. Nach dem Veitsdom handelt es sich dabei um den zweiten Bau dieses Typs in Böhmen. Gemäß der von V. Mencl präsentierten Rekonstruktion, die unserem bisherigen Kenntnisstand am meisten entspricht, wurde auf dem Vyšehrad das System der südfranzösischen Basiliken von Toulose und Narbonne nachgeahmt. Den Grabungsergebnissen nach erreichte der Kapitelkomplex Ende 14. und Anfang 15. Jahrhundert eine Länge von $110 \mathrm{~m}$ und war damit im vorhussitischen Prag eines der längsten Bauwerke seiner Zeit.

Die Problematik und Interpretation der archäologischen Grabung der Kapitelkirche lässt sich folgendermaßen zusammenfassen: Im Bereich des Vyšehrader Friedhofs wurde bei der archäologischen Grabung (ca. 35 m) östlich vom Abschluss des Südschiffs der heutigen Kirche ein Teil einer eingetieften Apsis sowie Abschnitte des Fundamentmauerwerks des Südschiffs entdeckt, das offensichtlich an die Apsis anschloss und sich weiter bis unter den heutigen Bau erstreckt (Nechvátal 2004, 247, Taf. XVII.). Ferner wurden hinter der Sakristei auf der Nordseite am heutigen Chorraum weitere Fundamentüberreste entdeckt. Diese Tatsache ermöglichte es zusammen mit dem durch weitere archäologische Grabungen im Innern des heutigen Kapitelgebäudes entdeckten Mauerwerk, die Grundrissform der frühmittelalterlichen dreischiffigen Basilika zu rekonstruieren, die Teil von Vratislavs Gründung war. Die Basilika hatte ein annähernd 7,5 m breites Hauptschiff und ca. 3,6 m breite Seitenschiffe. Ihre Länge betrug ca. $53 \mathrm{~m}$, und die Breite $17 \mathrm{~m}$. Ferner wurde durch die Grabung festgestellt, dass die Lage der romanischen Brücke der direkten Verbindungslinie zwischen der Königsakropolis und dem Innenraum der Kapitelkirche entspricht. Auch trotz intensiver Grabungen im Bereich des Vyšehrader Friedhofs ist uns die Lage von zwei offenbar symmetrisch angeordneten Türmen, zwischen denen sich die Fürsten- und Königskrypta befand, unbekannt. In diesem Zusammenhang wurde auch die Hypothese über einen älteren Ursprung des barocken Glockenturms überprüft, der am Ende des (1885-1903 erfolgten) neogotischen Umbaus abgerissen wurde. Als seine Lage in den Plan der im Bereich des Vyšehrader Friedhofs durchgeführten archäologischen Grabung eingetragen wurde, hat man festgestellt, dass sich seine Südmauer direkt an der nördlichen Außenmauer der romanischen Basilika befand. Er hat sie voll und ganz respektiert, und es ist offensichtlich, dass er den Ergebnissen der archäologischen Grabung nach mit ihm verbunden war (Nechvátal 2004, 247, Tab. XVII.). Das bedeutet, dass er während einem nicht näher bestimmten Zeitraum zur gleichen Zeit wie die Basilika in Betrieb gewesen war.

Ein grundlegender Überblick über die bauliche Entwicklung der Peter-und-Paul-Kirche auf dem Vyšehrad macht es zugleich auch möglich, auf Interpretationsmöglichkeiten und auf einige bisher nur unzufriedenstellend geklärte und immer noch offene Fragen hinzuweisen, mit denen wir uns näher vertraut machen und detaillierter auseinandersetzen wollen. Dies betrifft vor allem die zweite romanische Etappe vor dem Jahr 1129, die Altarplatte aus der Basilika San Piero a Grado von Pisa und ihr Bezug zum Vyšehrad, ein Reliefmedaillon mit Adlermotiv und den Rundbau des Baptisteriums vor der Westfassade der frühromanischen Basilika.

Der vorliegende Beitrag gründet sich auf den Ergebnissen des Förderprojekts des Ministeriums für Kultur der Tschechischen Republik und des Archäologischen Instituts der Tschechischen Republik - „Die Kapitelkirche St. Peter und Paul auf dem Vyšehrad. Archäologische Untersuchung“ - PK 01 PO 40 PP 005-411.

PhDr. Bořivoj Nechvátal, CSc., Archeologický ústav AV ČR, Praha, v. v. i., výzkum Vyšehrad, Štulcova 4, 12000 Praha, Česká republika, tel. 224918 758,nechvatal@arup.cas.cz 
